تأثثير إستخدام التدريب المتباين لتنمية بعض القدرات البدنية الخاصة على المستوى الرقمى فى قذف القرص. حسام كمال الدين محمود أبو المعاطى قسم نظريات وتطبيقات مسابقات الميدان و المضمار - كلية التربية الرياضية بنين - جامعة الزقازيق- جمهورية مصر العربية.

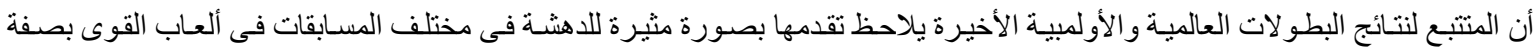

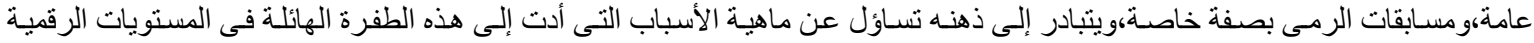

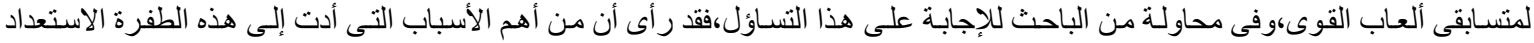

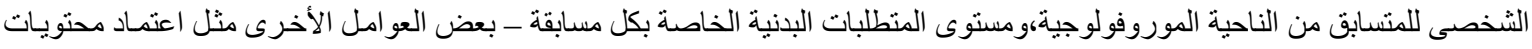

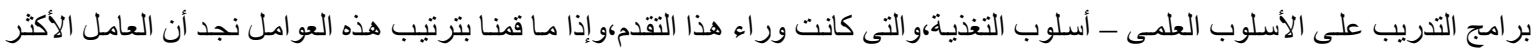
أهمية هو ما يختص ببر امج التدريب الرياضى،و الطرق و الوسائل المستخدمة فى تطوير المنطلبات البدنية الخاصة بكل مسابقة.

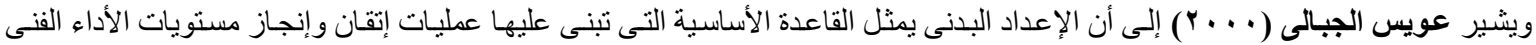

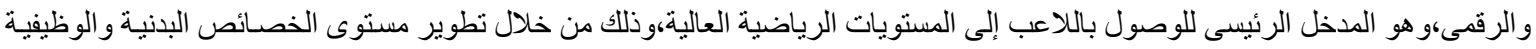

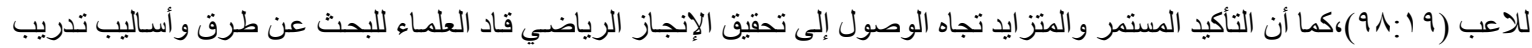

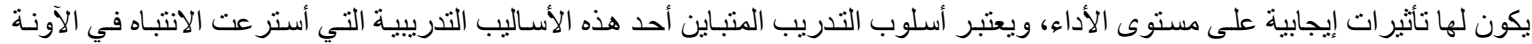

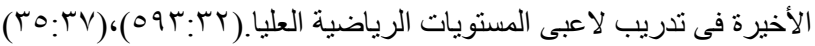

ويذكر محمد إبراهيم شحاته (9 و 9 ( ) أن الأهداف الرئيسية لبر امج التدريب بالأثقال لكل الرياضيين هو تنمية وتطوير القوة العضلية والقدرة

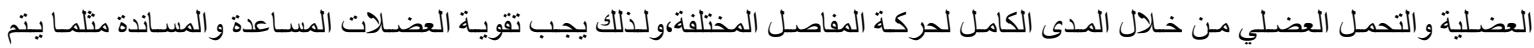

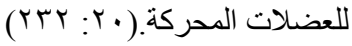

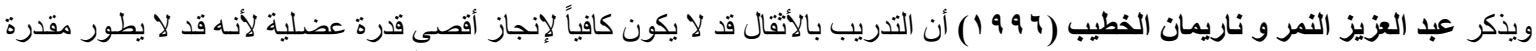

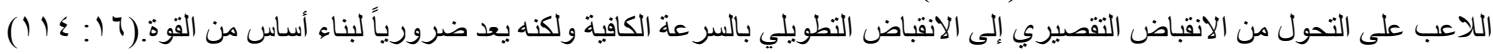

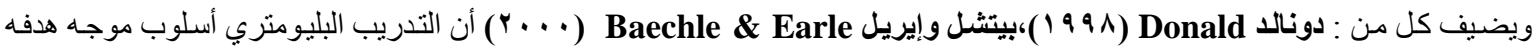

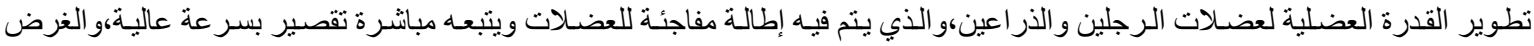

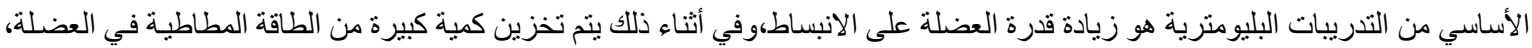

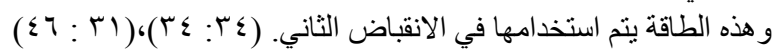

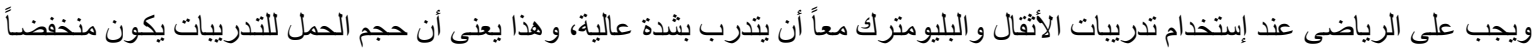

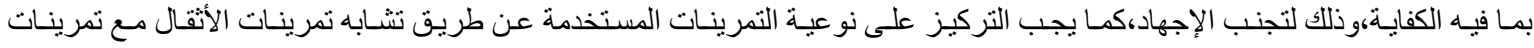

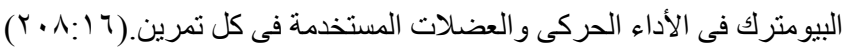

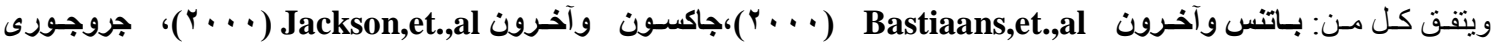
(Y. . V)Grogory

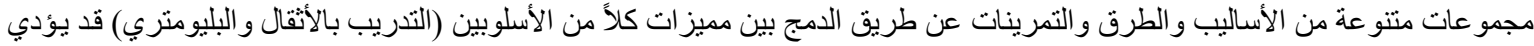

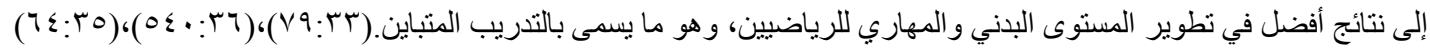

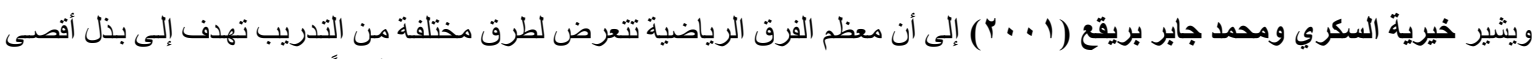

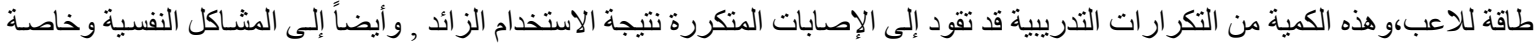

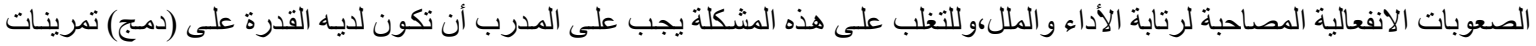

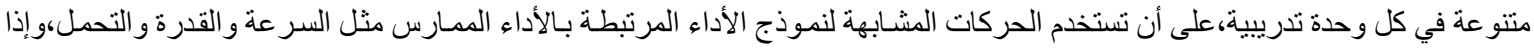

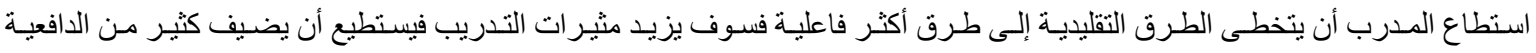

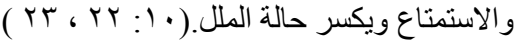

ويذكر السيد عبد المقصود ( و9 ( ) أن التدريب المتباين يهدف إلى تجنب مسار التدريب على وتيرة واحدة عن طريق الاقتصار على استخدام طرق التدريب المعتاد عليها،ويتم التغيير في هذا الأسلوب من خلال تتابع استخدام أوزان خفيفة وثقيلة مع الاجنهاد في أن يكون أسلوب الأبن الأداء 


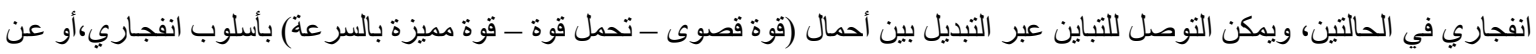

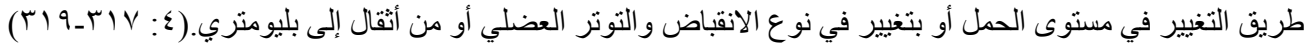

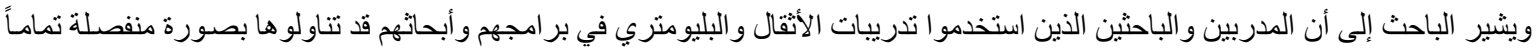

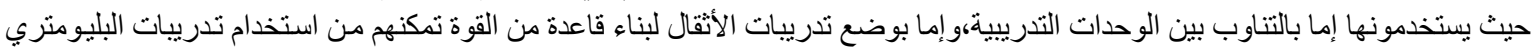

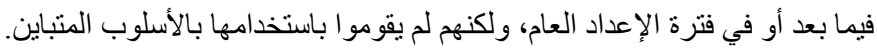

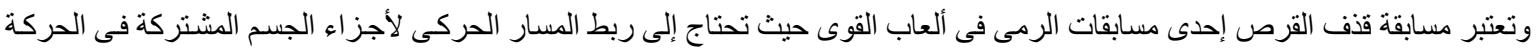

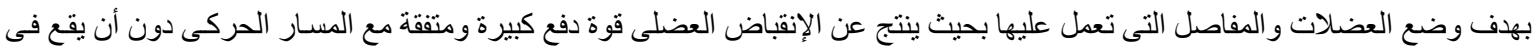

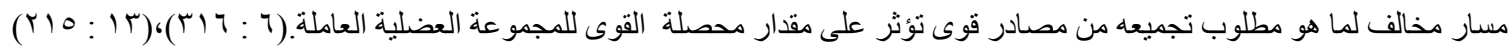

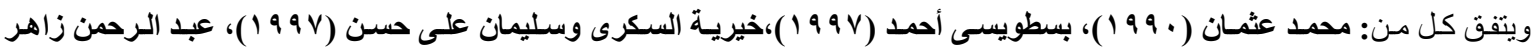

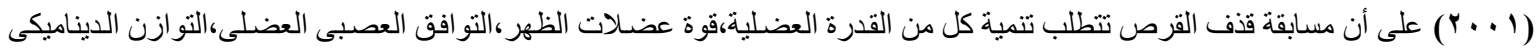

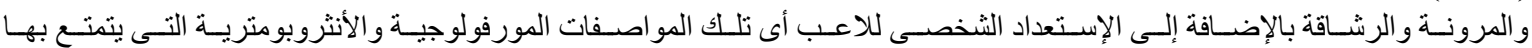

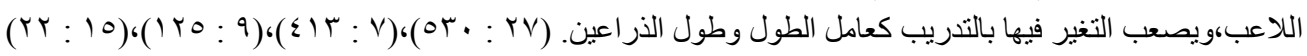

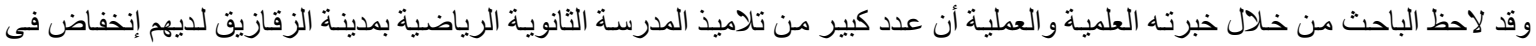

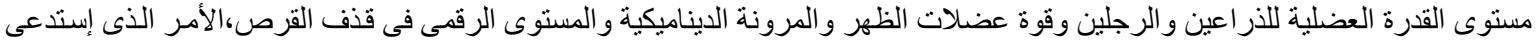

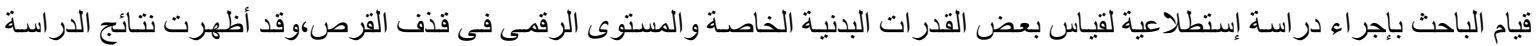

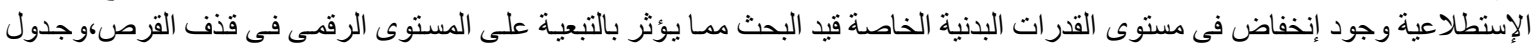
(1) يوضح نتائج الدراسة الإسنطلاعية الأولى الفئ

جدول (1)

نتائج الدراسة الإستطلاعية الأولى

\begin{tabular}{|c|c|c|c|c|}
\hline الإنحراف المعياري & المتوسط الحسابي & وحدة القياس & القدرات البدنية & 5 \\
\hline. ro & r.tr & 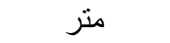 & القدرة العضلية للذر اعين & 1 \\
\hline .11 & 1.10 & متر & القدرة العضلية للرجلين & $r$ \\
\hline r.YE & $0 \leq .9$. & كجم & قوة عضلات الظهر & $\varepsilon$ \\
\hline T.71 & $0 \wedge . V$. & درجة & التوازن الديناميكى & 0 \\
\hline r.Ar & YI.0. & عدد & المرونة الديناميكية & 7 \\
\hline $.9 r$ & $r \cdot . \leqslant 1$ & 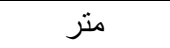 & المستوى الرقمى فى قذف القرص & $\mathrm{V}$ \\
\hline
\end{tabular}

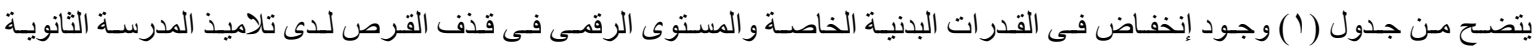
الرياضية،و بالتالى وجود مشكلة تتطلب حلول علمية.

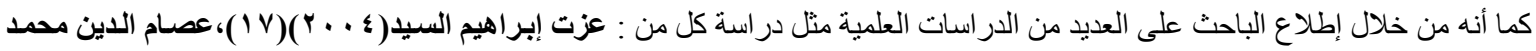

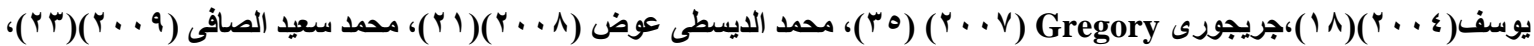

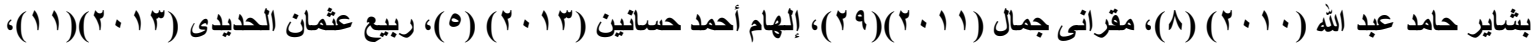

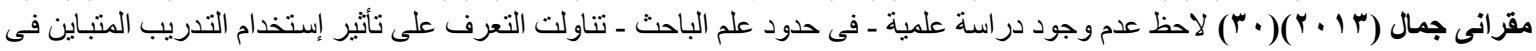

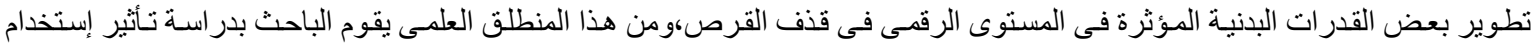

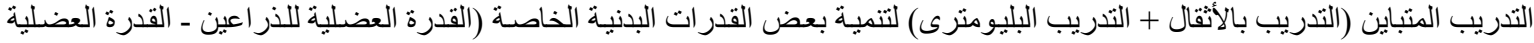

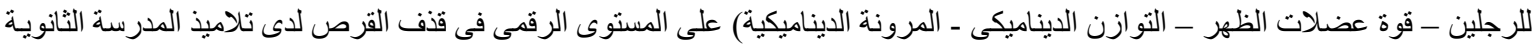

الرياضية بالزقازيق.

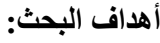

يهدف هذا البحث إلى وضـع برنـامج تدريبي بإستخدام التدريب المتباين (التدريب بالأثقال + التدريب البليومترى) لتلاميذ المدرسـة الثانويـة الرياضية ومعرفة تأثيره على:

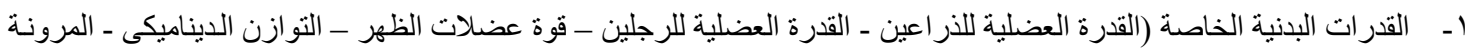

الديناميكية) لدى تلاميذ الددرسة الثانوية الرياضية.

r- المستوى الرقمى فى قذف القرص لدى تلاميذ المدرسة الثانوية الرياضية. 
ا - يؤثر البرنامج التدريبي بإستخدام التدريب المتباين تأثثيراً إيجابياً على القدرات البدنيـة الخاصـة (القدرة العضلية للذر اعين ـ القدرة

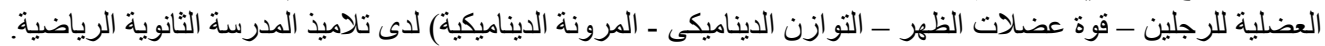

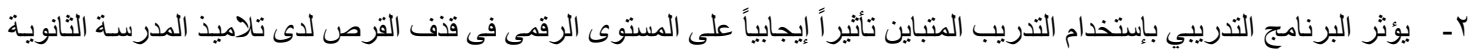

الرياضية.

مصطلحات البحث:

التدريب المتباين Variable Training

هو " أسلوب تدريبي يتم فيه محاولة التوصل إلى أقصى درجة من الفاعلية عن طريق استخدامات القوة بأساليب منباينة أو منضسادة في الاتجاه

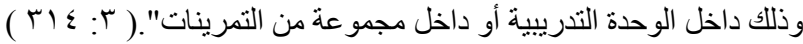

الاراسات المرتبطة :

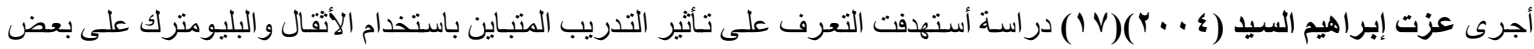

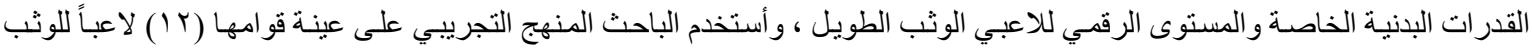

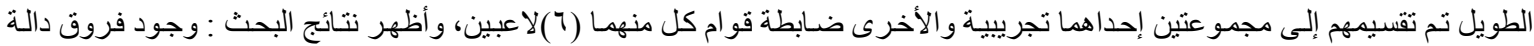

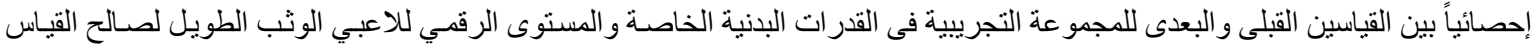

البعدى

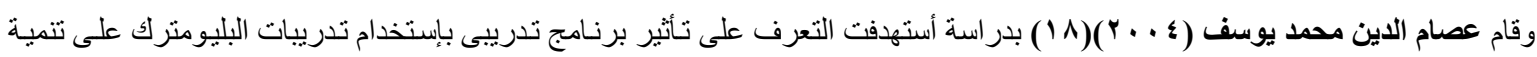

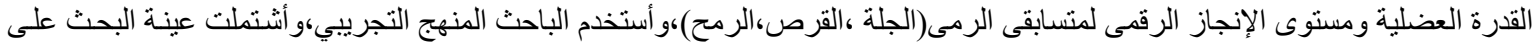

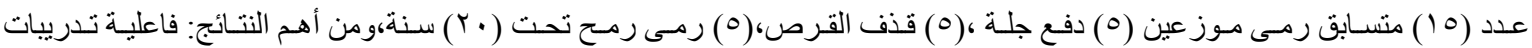

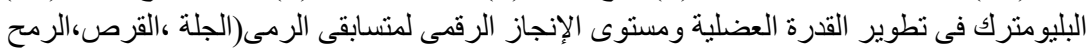

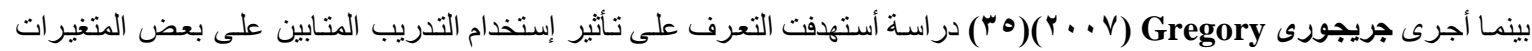

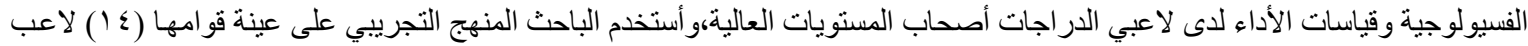

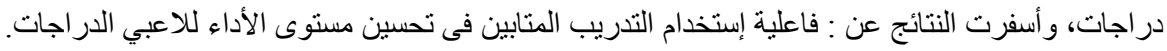

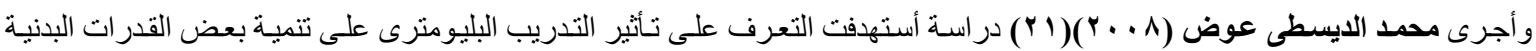

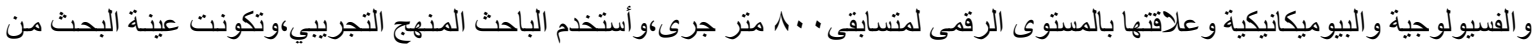

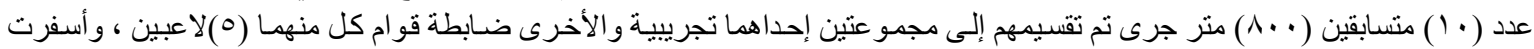

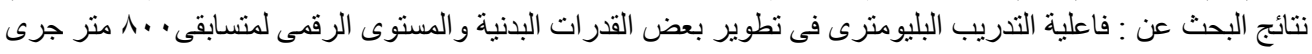

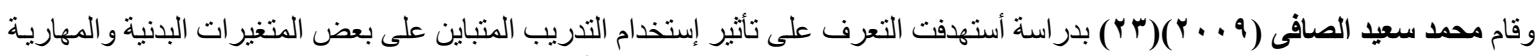

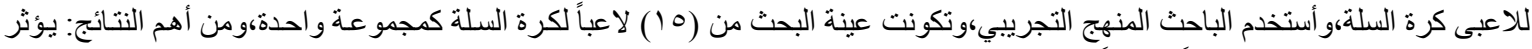

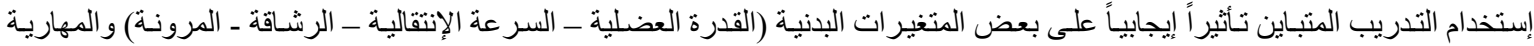

للاعبى كرة السلة

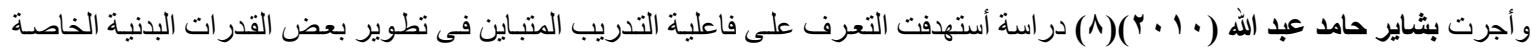

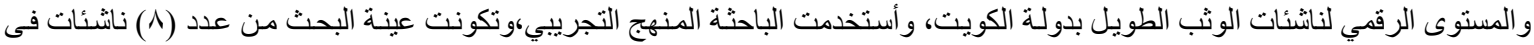

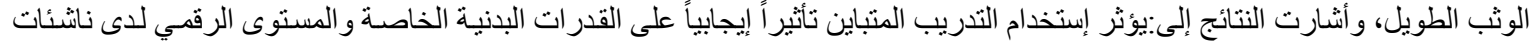

الوثب الطويل.

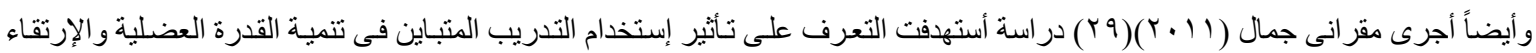

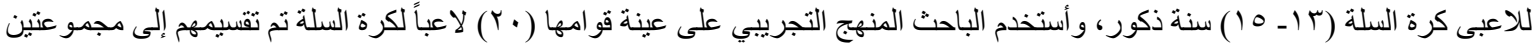

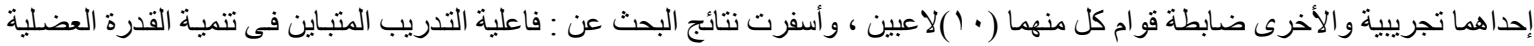

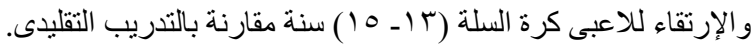

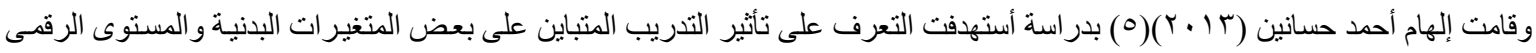

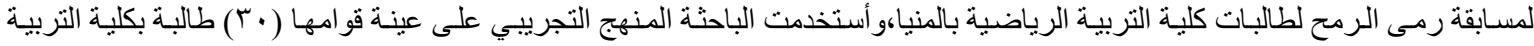

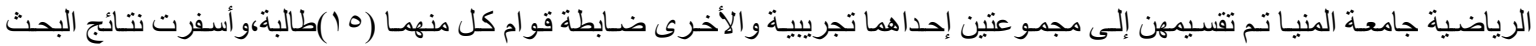


عن:وجود فروق دالة إحصائياً بين القياسين القبلى و البعدى للمجموعة التجرييية فى المتغيرات البدنية و المستوى الرقمى لمسابقة رمى الرمح

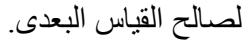

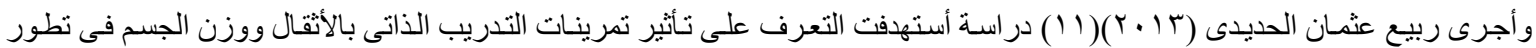

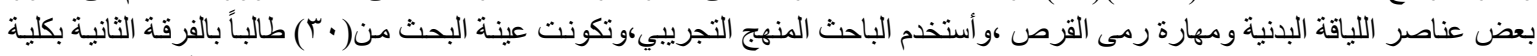

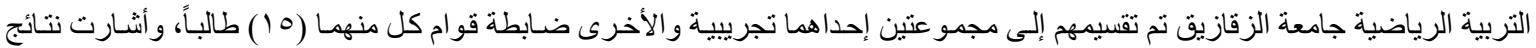

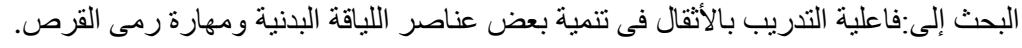

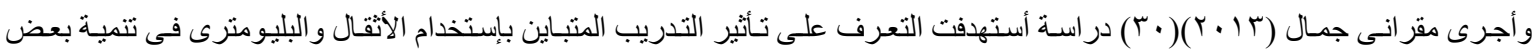

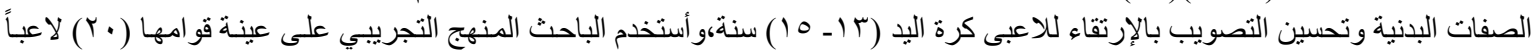

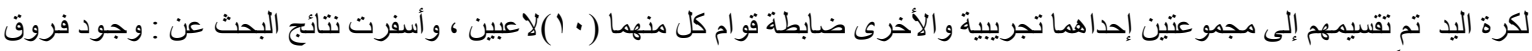

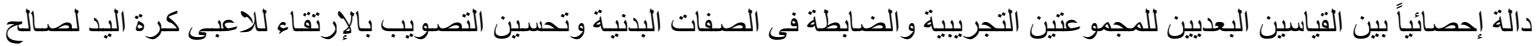

المجموعة التجريبية.

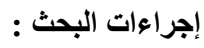

منهج البحث :

أستخدم الباحث المنهج التجريبـ،وتم الإستعانة بأحد التصميمات التجريبي،و هو التصميم التجريبـى لمجمو عتين تجريبية وضـابطة بإستخدام القياس القبلى البعدى للمجمو عتين.

مجتمع وعينة البحث:

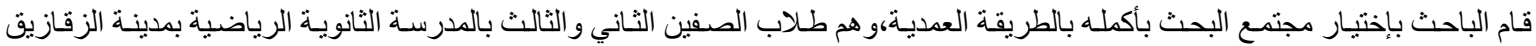

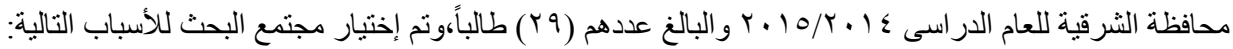

-

سبق لهم تعلم مسابقة قذف القرص بالصف الأول الثنانوى.

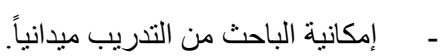

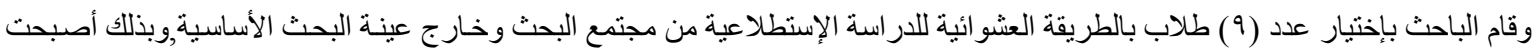

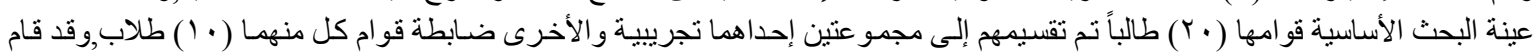

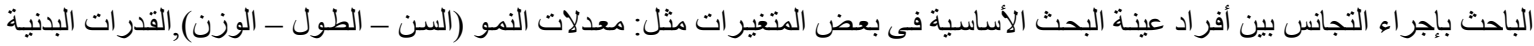

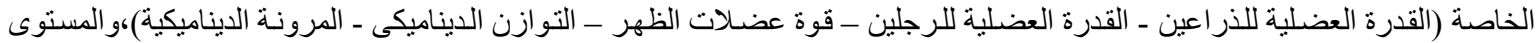

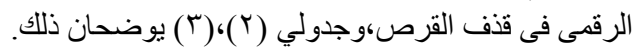

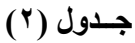

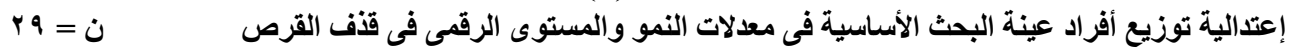

\begin{tabular}{|c|c|c|c|c|c|}
\hline معامل الإلتو اء & الوسيط & الإنحر اف المعيارى & المتوسط الحسابى & وحدة القياس & المتغير ات \\
\hline.$\wedge \varepsilon$ & $17 . \leqslant 0$ & .199 & 17.8. & سنة & 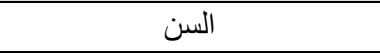 \\
\hline$\because \vee \wedge$ & 170.0 & 0.11 & $177 . \wedge r$ & سم & الطول الكلى للجسم \\
\hline.$\wedge V$ & $T \varepsilon .$. & $r .97$ & 70.10 & كجم & 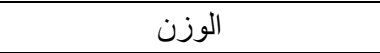 \\
\hline .00 & r... & T.V & 41.0. & متر & المستوى الرقمى فى قذف القرص \\
\hline
\end{tabular}

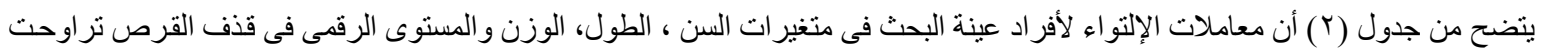

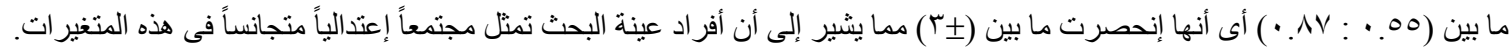

جدول (r)

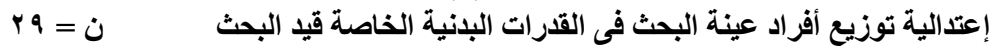

\begin{tabular}{|c|c|c|c|c|c|}
\hline معامل الالتواء & الوسبط & الالمعرافي & المستوسط & وحدة القياس & المتغيرات \\
\hline.$\wedge$. & T.0. &.$\mu$ & $r .01$ & متر & القدرة العضلية للذر اعين \\
\hline
\end{tabular}




\begin{tabular}{|c|c|c|c|c|c|}
\hline معامل الالتواء & الوسيط & الالمعراف & الحستوسط الحسى & وحدة القياس & المتغيرات \\
\hline .01 & $1 . \wedge$. & $.1 \mathrm{~V}$ & l. & منر & القدرة العضلية للرجلين \\
\hline.$\wedge 7$ & $0 \leq 0$. & $r . \wedge q$ & 00.74 & كجم & قوة عضلات الظهر \\
\hline . & ov. vo & r. & $01 . \vee 0$ & درجة & التوازن الديناميكى \\
\hline .90 & $r \cdot \cdots$ & מח.r & YI.0 & عدد & المرونة الديناميكية \\
\hline
\end{tabular}

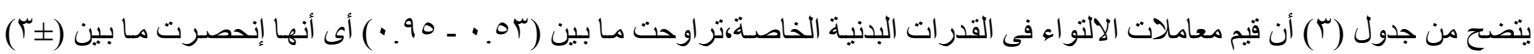

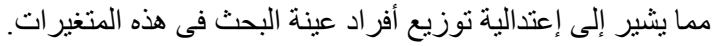

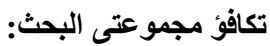

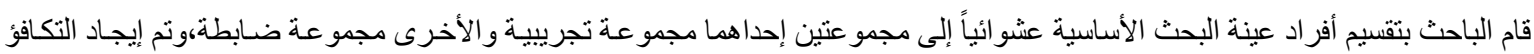

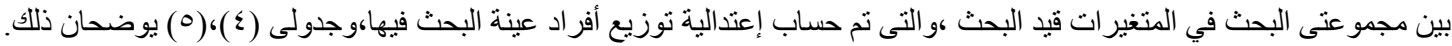

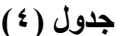

دلالة الفروق بين المجموعتين التجريبية والضابطة فى معدلات النمو والمستوى الرقمى فى قذف القرص

\begin{tabular}{|c|c|c|c|c|c|c|}
\hline \multirow[t]{2}{*}{ قيمة "ت" } & \multicolumn{2}{|c|}{ المجموعة الضابطة ن = } & \multicolumn{2}{|c|}{ المجموعة التجريبية ن= } & \multirow{2}{*}{ والقياس } & \multirow[t]{2}{*}{ المتغيرات } \\
\hline & $\varepsilon$ & 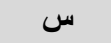 & $\varepsilon$ & 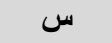 & & \\
\hline .79 & ( & 17.7. & .01 & $17 . \wedge$ & سنة & السن \\
\hline$\because \leqslant r$ & $\varepsilon .1 \mathrm{~V}$ & $177 . \leqslant 1$ & (T) & ITV.YO & سم & الطول الكلى للجسم \\
\hline$\because V Y$ & r.q & $7 \leqslant .0$ & $r . v 1$ & 70.1. & 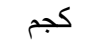 & 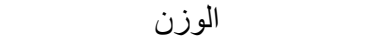 \\
\hline .10 & .91 & r... &.$\wedge r$ & M & 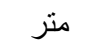 & المستوى الرقمى فى قذف القرص \\
\hline
\end{tabular}

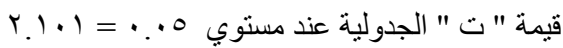

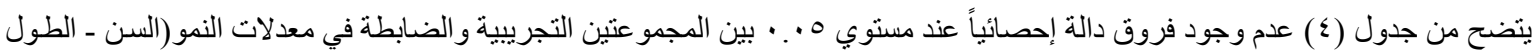

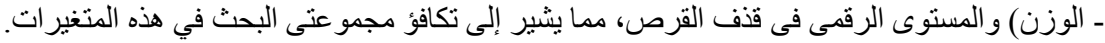

\section{جلمول (0)}

دلالة الفروق بين المجموعتين التجريبية والضابطة فى القدرات البدنية الخاصة قيد البحث

\begin{tabular}{|c|c|c|c|c|c|c|}
\hline \multirow[t]{2}{*}{ قيمة "ت" } & \multicolumn{2}{|c|}{ المجموعة الضابطة } & \multicolumn{2}{|c|}{ المجموعة التجريبية } & \multirow{2}{*}{ القياس } & \multirow[t]{2}{*}{ المتغيرات } \\
\hline & $\varepsilon$ & س - س & $\varepsilon$ & س س & & \\
\hline..$\leqslant 7$ & $\cdot r^{r}$ & 5.00 & $\cdot$ YO $^{\circ}$ & r.7. & مثر مثر & القدرة العضلية للذر اعين \\
\hline.$\wedge 1$ & $\because .0$ & $1 . \wedge 1$ & $\because 1$ & $1 . \wedge \varepsilon$ & متر & القدرة العضلية للرجلين \\
\hline .01 & $r .49$ & $00 . r T$ & $r . \leqslant 7$ & 00.91 & كجم & قوة عضلات الظهر \\
\hline$\cdot .4$ & r.VI & 01.0. & 5.19 & $09 .$. & درجة & التوازن الديناميكى \\
\hline$\cdot r q$ & r.ru & $r \cdot . q \cdot$ & 5.10 & r..r. & عدد عد & المرونة الديناميكية \\
\hline
\end{tabular}

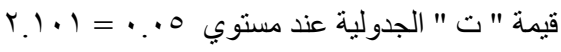
يتضح من جدول (0) عدم وجود فروق دالة إحصائياً عند مستوي ه •. • بين المجمو عتين التجريبية و الضابطة في القدرات البدنية الخاصـة،مما

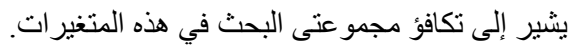

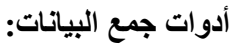
أولاً : إستطلاع رأى الخبراء: 


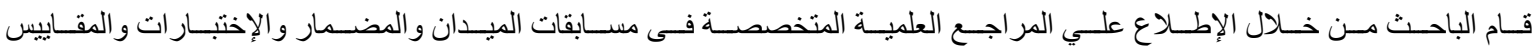

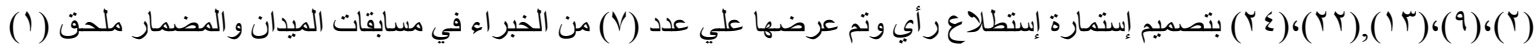
لإستطلاع رأيهم في ما يلى :

- أهم القدرات البدنية الخاصة بلاعبى قذف القرص و أهم الإختبار ات التي تقيسها. ويوضح جدول (ך) أهم القدرات البدنية الخاصة بلاعبى قذف القرص وفقاً لآراء الخبر اء:

(7) جدول

النسب المئوية وفقاً لآراء الخبراء فى القدرات البدنية الخاصة بلاعبى قذف القرص

\begin{tabular}{|c|c|c|c|c|}
\hline الترتيب & النسبة المئوية & عدد الآراء الموافقة & القدرات البذنية الخاصة & r \\
\hline الأول & $\% 1 \cdots$ & V & القدرة العضلية للذر اعين. & 1 \\
\hline الر ابع & $\% \wedge 0 . \vee 1$ & 7 & القدرة العضلية للرجلين. & $r$ \\
\hline السادس & $\% \vee 1 . \varepsilon r$ & 0 & قوة القبضة يمين / شمال & $r$ \\
\hline السادس مكرر & $\% \vee ! \leqslant r$ & 0 & التو افق. & $\xi$ \\
\hline الأول مكرر & $\% 1 \ldots$ & V & التو ازن الديناميكى. & 0 \\
\hline الأول مكرر & $\% 1 \ldots$ & $\mathrm{V}$ & قوة عضلات الظهر & 7 \\
\hline الثامن & $\% \leq r . \wedge T$ & $r$ & التوازن الثابت. & 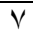 \\
\hline الر ابع مكرر & $\% \wedge 0 . \vee 1$ & 7 & المرونة الديناميكية. & $\Lambda$ \\
\hline
\end{tabular}

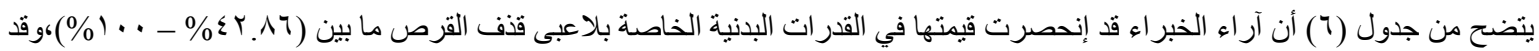

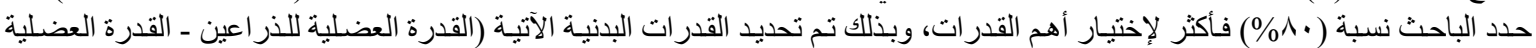

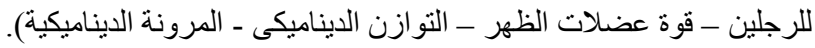

وقام الباحث بتحديد الإختبار ات البدنية التي تقيس القدرات البدنية ملحق (r) وفقاً لآر اء الخبر اء فكانت كما يلي :

$$
\begin{aligned}
& \text { ا - إختبار دفع كرة طبية (r) كجم لأقصى مسافة. } \\
& \text { Y- إختبار الوثب العريض من الثبات. } \\
& \text { r- إختبار قوة عضلات الظهر. }
\end{aligned}
$$

ثانياً : قياس المستوى الرقمى فى قذف القرص: تم قياس المستوى الرقمى فى قذف القرص لأفر اد عينة البحث الأساسية عن طريق قياس المسافة الذى يقطعها القرص بالمتر و لأقرب سم،وذللك

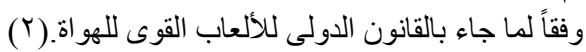

ثالثاً : الأجهزة والأدوات المستخدمة في البحث: - - ل - - ميز ان طبي معاير لقياس الوزن. - -

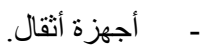
- شريط لاصق. ، شريط قياس ، ساعة إيقاف. - كرات طبية زنة (؟) كجم ، عدد من الأقر اص القانونية ومقطع للرمى - المعاملات العلمية (الصدق - الثبات) للإختبارات قيا البحث:

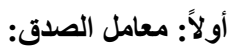


أستخدم الباحث طريقة صدق التمايز للتحقق من صدق الاختبار ات البدنيـة قيد البحث،وذللك بإيجاد دلالة الفروق بين نتائج مجمو عتين إحداهما

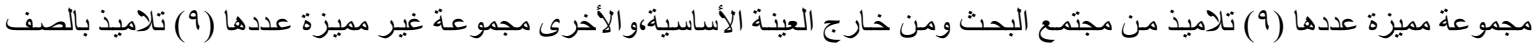

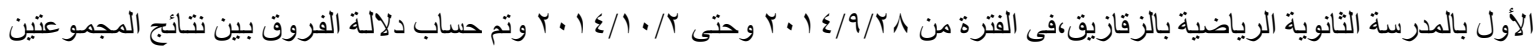

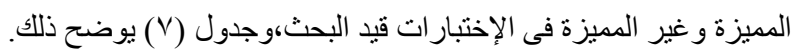

جدول (v)

دلالة الفروق بين المجموعتين المميزة وغير المميزة فى الإختبارات قيد البحث

\begin{tabular}{|c|c|c|c|c|c|c|}
\hline \multirow{2}{*}{ "تيمة } & \multicolumn{2}{|c|}{ المجموعة غير المميزة ( ن=9) } & \multicolumn{2}{|c|}{ المجموعة المميزة ( ن=9) } & \multirow{2}{*}{ القياس } & \multirow{2}{*}{ الإختبارات } \\
\hline & $\varepsilon$ & س س & $\varepsilon$ & س & & \\
\hline$* Y . \leqslant 0$ &.$r T$ & 5.10 & $\cdot r \cdot$ & r.or & متر & القدرة العضلية للذر اعين \\
\hline$* Y . \Gamma \varepsilon$ & .10 & $1 . v$ & .1 & 1.10 & منر & القدرة العضلية للرجلين \\
\hline *r. YV & r.te & 01.0. & r. rq & 00.1 & 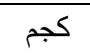 & قوة عضلات الظهر \\
\hline$* r . q \wedge$ & r. $9 \leq$ & $00 .$. & Y.VI & 09.1. & درجة & التوازن الديناميكى \\
\hline$* Y .70$ & 4.17 & $r \cdot .1 \cdot$ & t. tr & rt... & عدد & المرونة الديناميكية \\
\hline
\end{tabular}

* دال عند مستوي 0 •.

قيمة " ت " الجدولية عند مستوي 0.

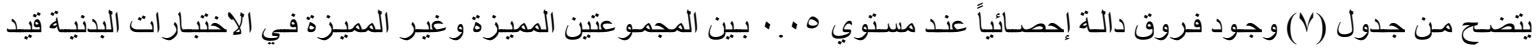
البحث،ولصالح المجمو عة المميزة مما يشير إلي صدون فئن الاختبار ات فيما تقيس.

ثانياً: معامل الثبات:

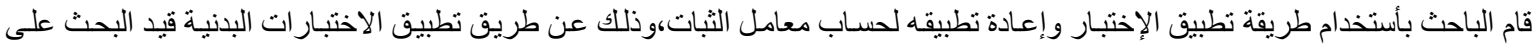

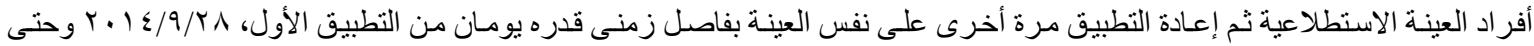

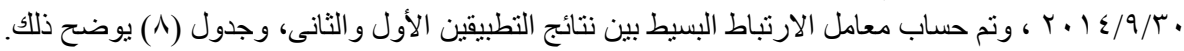

جدول (^)

معامل الثبات للاختبار

\begin{tabular}{|c|c|c|c|c|c|c|}
\hline \multirow{2}{*}{ قيمة "ر" } & \multicolumn{2}{|c|}{ التطبيق الثاني } & \multicolumn{2}{|c|}{ التطبيق الأول } & \multirow{2}{*}{ والقياس } & \multirow{2}{*}{ الإختبار ات } \\
\hline & $\varepsilon$ & س - ن & $\varepsilon$ & 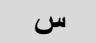 & & \\
\hline$* . \vee \vee 79$ & $\cdot r r$ & r. & $\cdot r \cdot$ & r.or & متر & القدرة العضلية للذر اعين \\
\hline$* . \wedge 90$ & $\because 0$ & I.AV & $\because 1$ & 1.10 & متر & القدرة العضلية للرجلين \\
\hline$* . V \vee V$ & r.IT & $00 . V$. & r. rq & $00 . M$ & كجم & قوة عضلات الظهر \\
\hline$* . . \vee \leqslant 9$ & Y.97 & $7 . .0 Y$ & Y.VI & 09.4. & درجة & التوازن الديناميكى \\
\hline$*$. * V V & r.l. & rT.0T & T. Kr & $r$ r... & عدد & المرونة الديناميكية \\
\hline
\end{tabular}

* دال عند مستوي 0 •.

قيمة " ر " الجدولية عند مستوي 0.. = =

يتضح من جدول (^) وجود علاقة إرنباطية دالة إحصائياً عند مستوي ه . • بين نتائج التطبيقين الأول والثانى للإختبار ات البدنية قيد البحث

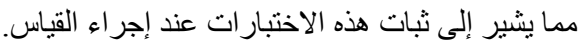

الار اسة الاستطلاعية الثانية :

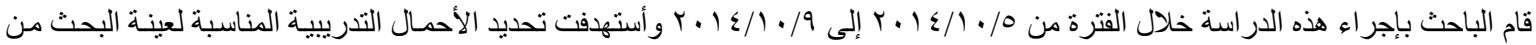

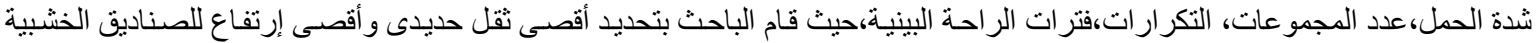

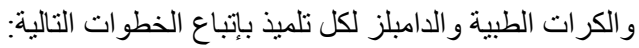

ا ـ عقب أداء التهيئة البدنية يقوم التلميذ بأداء مجموعة و احدة من (0) تكرار ات بثقل خفيف بإستخدام البار الأوليمبي بدون أثقال،ثم يقوم

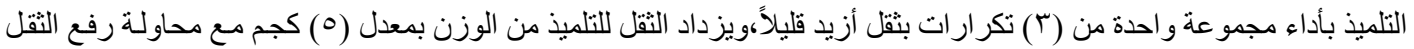


ץ- يتم التدرج فى زيادة التقل مع أداء تكر ار و احد فى كل مرة بطريقة صحيحة حتى الوصول إلى أقصى ثقل بستطيع التلميذ رفعه مرة واحدة.

بـ يقوم التلميذ بأداء الوثب العميق و الوثب العميق مع الفجوة من فوق صناديق خشبية متعددة الإرتفاعات تبدأ من ( • لسم) ثم الوثب

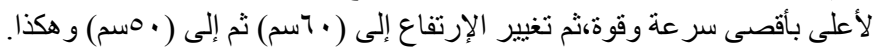
ع - يقوم التلميذ بدفع الكرات الطبية مختلفة الأوزان تبدأ من (0 كجم) ثم تغيير الوزن إلى (ع كجم) ثم إلى (س كجم) و هكذا. وقد أسفرت نتائج الدر اسة الاستطلاعية الثانية عن ما يلى: - تم تحديد بداية الإرتفاعات للصناديق الخثبية فى تدريبات البليومترك بـ (هـم). - تم تحديد بداية أوزان الكرات الطبية (r كجم) والدامبلز (r) كجم.

كما قام الباحث بتطبيق مجموعة تدريبات البليومنرك على أفر اد المجموعة التجرييية، وذلك للتعرف على أقصى تكر ار لكل تدريب،وتحديد إرتفاعات الصناديق الخشبية فى تدريب الوثب العميق وأوز ان الكرات الطبية،وتحديد المجموعات وفترات الراحة بين المجموعات.

البرنامج التدريبى المقترح بإستخدام التدريب المتباين: أولاً : الهُف من البرنامج التدريبى المقترح: ا - تطوير بعض القدر ات البدنية الخاصة بقذف القرص لدى تلاميذ المدرسة الثانوية الرياضية بالزقازيق. r - ت تحسين المستوى الرقمى فى قذف القرص لدى تلاميذ المدرسة الثانوية الرياضية بالزقازيق. ثانياً : أسس وضع البرنامج التدريبى المقترح : عند وضع محتوى البرنامج التدريبي راعى الباحث الأسس العلمية التالية: ا - يجب أن يحقق محتوى البرنامج أهداف البحث الموضو عة و المحددة مسبقاً. r- مناسبة التمرينات المختارة مع قدرات أفر اد عينة البحث الأساسية.

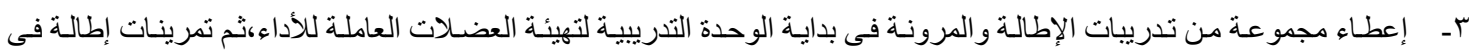
فتر ات الراحة.

ــ ـ يجب ألا يزيد عدد الوحدات التدرييية عن (T) وحدات فى الأسبوع حتى لا نصل إلى إجهاد التلميذ بدنياً. 0- البدء بتدريبات الأثقال أولاً يتبعها تدرييات البليومترك. 7- التنويع فى تدريبات الأثقال وتدريبات البليومترك داخل الوحدات التدريبية اليومية حتى لا يحدث ملل أو الأداء بشكل روتينى لعمل عضلى و احد فقط. - - يجب إعطاء فتر ات راحة إيجابية بين المجمو عات من (Y - r) دقائق لإستعادة الإسنشفاء. ^ــ تم تحديد أقصـى تكر ار لكل تلميذ مـن تدريبات الأثقال وتدريبات البليومترك للرجلين والذر اعين ، و الجذع ، وذلك لتحديد شـدة

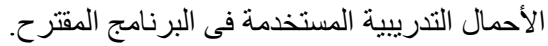

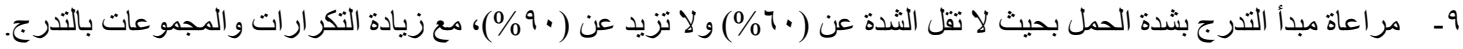

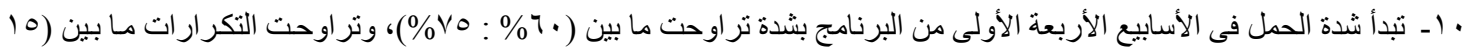

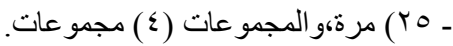

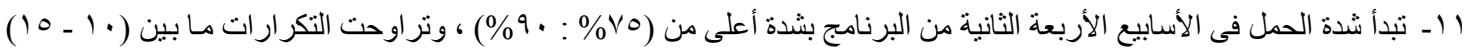

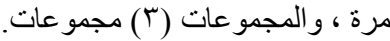

ثالثاً: مكونات حمل التدريب داخل البرنامج المقترح: ا. شدة الحمل:يجب أن تتدرج تدريبات الأثقال والبليومترى فى شدتها من الثدة الخفيفة إلى المتوسطة ثم العالية، وفى كل مرحلة

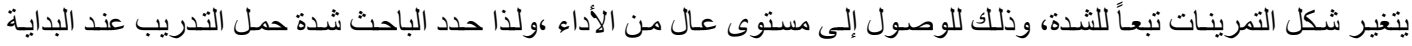

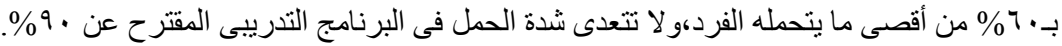




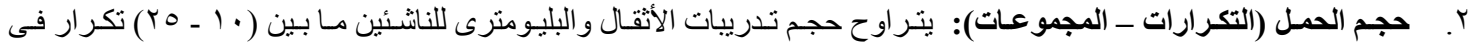

المجمو عة الو احدة، وأن تتراوح المجمو عات ما بين (r ـ 0) مجمو عات.( (1) 117 (1) )

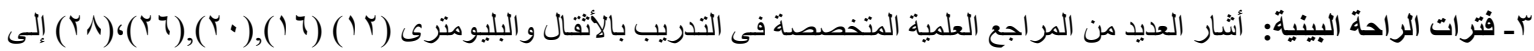

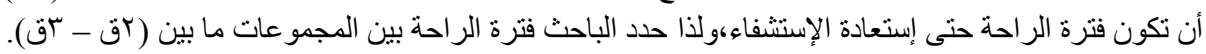

رابعاً: محتوى البرنامج التدريبي :

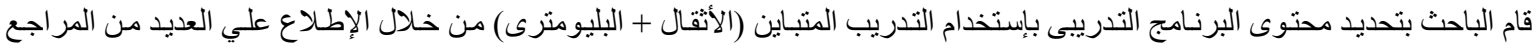

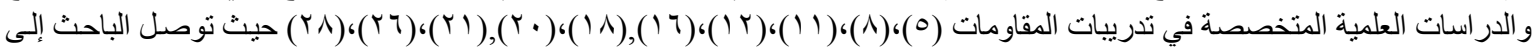

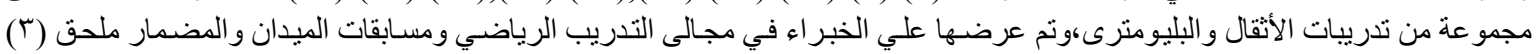
وذللك لتحديد أنسب التمرينات لمستوي أفراد عينه البحث الأساسية ومن خلال هذا الإجر اء تم التوصل التهل إلى التدريبات التالية:

أ - أ - تدريبات الأثقال:

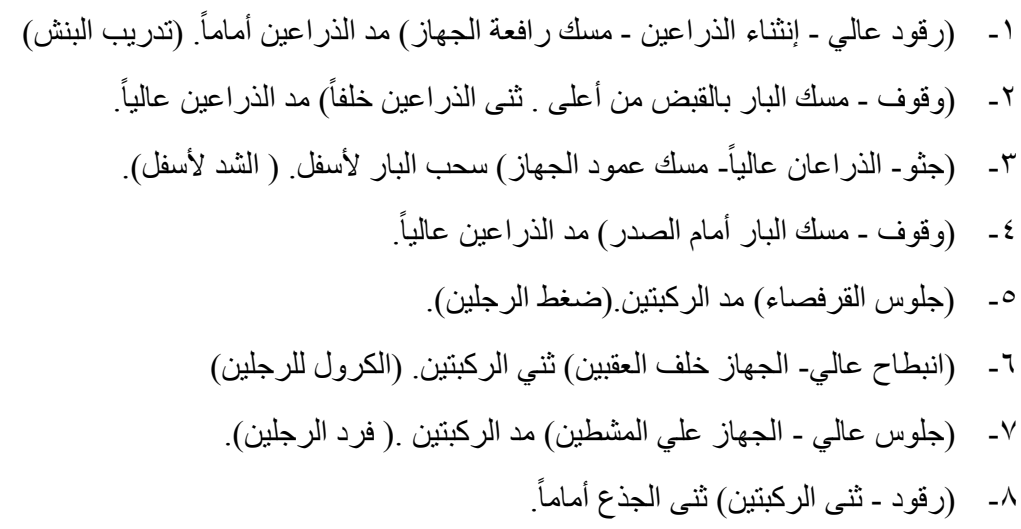

ب ـ ت تدريبات البليومترك:

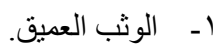

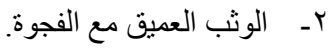

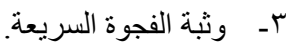

ع- ـ الحجل للجانب.

0- - التمريرة الصدرية بالكرة الطبية.

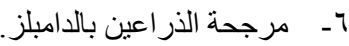

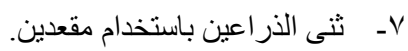

ه- - م- المرجحة الأفقية.

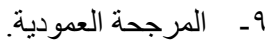

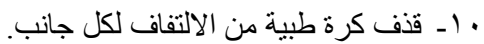

خامساً : التوزيع الزمنى للبرنامج التريبى بإستخدام التدريب المتباين:

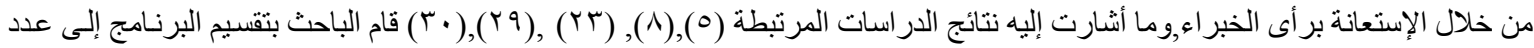

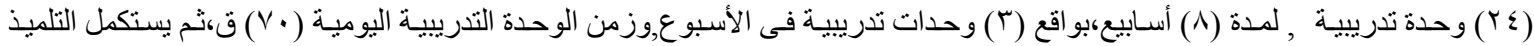

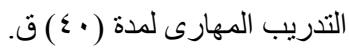

سادساً: أجزاء الوحدة التدريبية اليومية:

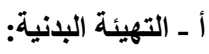


زمن هذا الجزء (0 (1) دقيقة ويؤديـه جميع أفر اد المجمو عتين التجريبيـة والضـابطة،وذللك لتهيئة الجهازين الدورى والتنفسى مع التركيز على تمرينات الإطالة و المرونة.

ب- الجزء الرئيسى:

زمن الجزء الرئيسى ( •0) دقيقة ، ويشتمل على عدد (ع) تدريبات أثقال وبليومترى وفى هذا الجزء يتم تقسيم المجمو عتين.المجموعة التجريبية

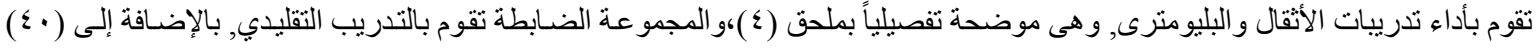
دقيقة تدريبات مهارية فى قذف القرص يشترك فيها أفر اد المجمو عتين التجريبية و الضابطة.

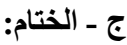

وزمن هذا الجزء (0) دقائق ويؤديه جميع أفر اد المجموعتين التجريبية والضابطة، ويتضمن تمرينات الإسترخاء،التهدئة و الإطالة الخفيفة. ويشير الباحث إلى أن محتوى البرنامج التدريبى بإستخدام التدريب المتباين موضح بملحق (0). القياسات القبلية:

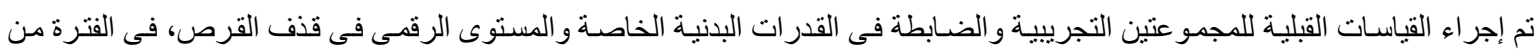

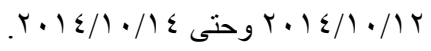

تطبيق البرنامج التدريبى المقترح :

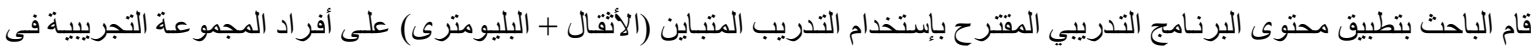

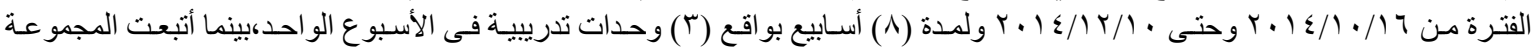

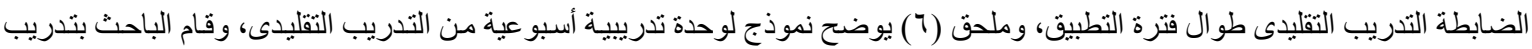

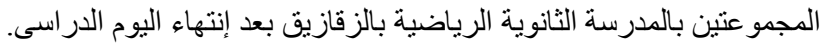

القياسات البعدية :

بعد الإنتهاء من مرحلة التطبيق للبرنـامج التدريبى تم إجر اء القياسـات البعديـة للمجمو عتين التجريبية و الضـابطة فى القدرات البدنيـة الخاصـة

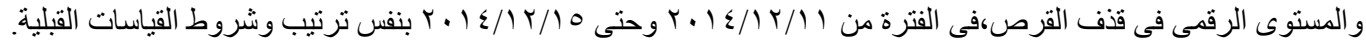

المعالجات الإحصائية:

قام الباحث بمعالجات البيانات إحصائياً،بإستخدام أساليب التحليل الإحصائى التالية:

Mean

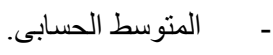

Standard Deviation

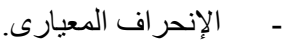

Mediain

-

Skewness

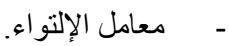

Correlation Cofficients

- معامل الإرتباط البسيط.

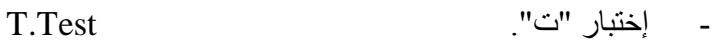

Progress Ratios

- - مسب التحسن.

- تبنى الباحث مستوى معنوية 0 . . حداً للالالة الإحصائية.

عرض ومناقشة النتائج:

أولاً : عرض النتائج:

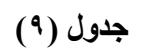

دلالة الفروق بين القياسين القبلى والبعدى للمجموعة التجريبية في القدرات البدنية الخاصة قيد البحث

\begin{tabular}{|c|c|c|c|c|c|c|}
\hline \multirow{2}{*}{ قيمة "ت" } & \multicolumn{2}{|c|}{ القياس البعدى } & \multicolumn{2}{|c|}{ القياس القبلى } & \multirow{2}{*}{ وقياس } & \multirow{2}{*}{ المتغيرات } \\
\hline & $\varepsilon$ & س & $\varepsilon$ & س & & \\
\hline
\end{tabular}




\begin{tabular}{|c|c|c|c|c|c|c|}
\hline \multirow{2}{*}{ قيمة "ت" } & \multicolumn{2}{|c|}{ القياس البعدى } & \multicolumn{2}{|c|}{ القياس القبلى } & \multirow{2}{*}{ وحدة القياس } & \multirow{2}{*}{ المتغير ات } \\
\hline & $\varepsilon$ & س & $\varepsilon$ & س & & \\
\hline$* 0 . Y \wedge$ & $\cdot Y_{1}$ & $\leqslant .10$ & $\cdot$ ro & r.7. & متر & لقدرة العضلية للذر اعين \\
\hline *ะ.M & $\because 0$ & $r \ldots$ & $\because 1$ & $1 . \wedge \varepsilon$ & متر & القدرة العضلية للرجلين \\
\hline$* r .97$ & I.VT & 09.10 & $r . \leqslant T$ & 00.91 & كجم & قوة عضلات الظهر \\
\hline$* 0 . \vee 1$ & Y.01 & $77 . Y$. & 5.19 & $09 .$. & ل & التوازن الديناميكى \\
\hline *0.rr & 1.87 & $r \uparrow . .$. & 9.10 & Y.Y. & عدد & المرونة الديناميكية \\
\hline
\end{tabular}

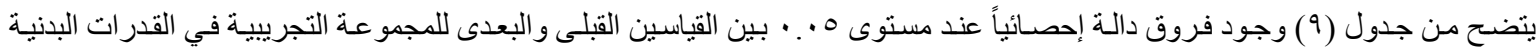

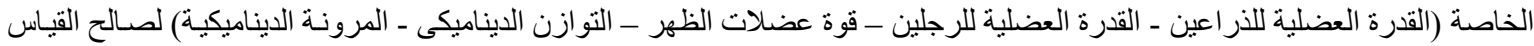

\section{جدول (·) (1) (2)}

دلالة الفروق بين القياسين القبلى والبعدى للمجموعة الضابطة في القدرات البذنية الخاصة قيد البحث

\begin{tabular}{|c|c|c|c|c|c|c|}
\hline \multirow{2}{*}{ قيمة "ت" } & \multicolumn{2}{|c|}{ القياس البعدى } & \multicolumn{2}{|c|}{ القياس القبلى } & \multirow{2}{*}{ والقياس } & \multirow{2}{*}{ المتغيرات } \\
\hline & $\varepsilon$ & س س & $\varepsilon$ & س س & & \\
\hline$* Y .17$ & $\because .19$ & r.Ar &.$Y_{1}$ & 5.00 & منر & القدرة العضلية للذر اعين \\
\hline$* Y . V Y$ & $\because .0$ & 1.9. & $\because .0$ & $1 . \wedge 1$ & متر & القدرة العضلية للرجلين \\
\hline$* Y, Y \wedge$ & 5.11 & $0 v_{0}$. & r.rq & $00 . \mu r$ & كجم & قوة عضلات الظهر \\
\hline *Y. 79 & t.r. & TY.T. & r.vi & 01.0. & درجة & التو ازن الديناميكى \\
\hline$* Y . \leqslant T$ & $1 . \wedge 1$ & rT.t. & t.tr & $r \cdot . q \cdot$ & عدد & المرونة الديناميكية \\
\hline
\end{tabular}

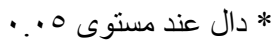

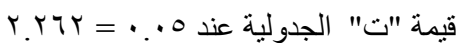

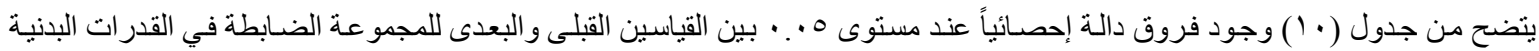

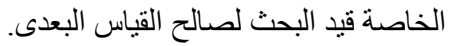

جدول (11)

دلالة الفروق بين القياسين البعديين للمجموعتين التجريبية والضابطة في القدرات البذنية الخاصة قيد البحث

\begin{tabular}{|c|c|c|c|c|c|c|}
\hline \multirow[t]{2}{*}{ قيمة "ت" } & \multicolumn{2}{|c|}{ المجموعة الضابطة } & \multicolumn{2}{|c|}{ المجموعة التجريبية } & \multirow[t]{2}{*}{ وحدة القياس } & \multirow[t]{2}{*}{ المتغيرات } \\
\hline & $\varepsilon$ & س - ن & $\varepsilon$ & س - س & & \\
\hline$* r . \leq q$ & .19 & $r . \wedge r$ & $\cdot .1$ & $\leqslant .10$ & متر & القدرة العضلية للذر اعين \\
\hline$* \varepsilon .1 \mathrm{~V}$ & $\because .0$ & 1.9 & $\because .0$ & r... & متر & القدرة العضلية للرجلين \\
\hline$* Y . \leq V$ & r.11 & ov. o. & $1 . V \mu$ & 09.10 & كجم & قوة عضلات الظهر \\
\hline *r.IT & r.rv & T.T. & Y.01 & T7.Y. & درجة & التوازن الديناميكى \\
\hline מזr.r* & 1.11 & rT.r. & 1.87 & $r 7 .$. & عدد & المرونة الديناميكية \\
\hline
\end{tabular}

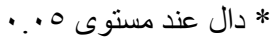

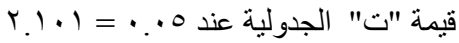

ينضح من جدول (1) (1) وجود فروق دالة إحصائياً عند مستوى ه .. • بين القياسين البعديين للمجمو عتين التجريبية و الضسابطة في القدرات البدنية الخاصة قيد البحث لصالح المجمو عة التجريبية.

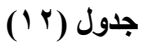

نسب تحسن القياس البعدى عن القبلى للمجموعتين التجريبية والضابطة في القدرات البدنية الخاصة قيد البحث

\begin{tabular}{|c|c|c|c|c|c|}
\hline \multicolumn{3}{|c|}{ المجموعة الضابطة } & \multicolumn{3}{|c|}{ المجموعة التجريبية } \\
\hline نسب التحسن & بعدى & قبلى & نسب التحسن & بعدى & قبلى \\
\hline
\end{tabular}




\begin{tabular}{|c|c|c|c|c|c|c|}
\hline \multicolumn{3}{|c|}{ المجموعة الضابطة ن= 1 } & \multicolumn{3}{|c|}{ المجموعة التجريبية } & \multirow{2}{*}{ المتغيرات } \\
\hline نسب التحسن & 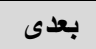 & قبلى & نسب التحسن & 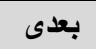 & قبلى & \\
\hline$\% \vee .71$ & r.Ar & $r .00$ & $\% 10.4 \wedge$ & $\leqslant .10$ & r. & القدرة العضلية للذر اعين \\
\hline$\% \leqslant .9 V$ & 1.9 & $1 . \wedge 1$ & $\% \wedge . \vee$. & r... & $1 . \wedge \varepsilon$ & القدرة العضلية للرجلين \\
\hline$\% r .94$ & ov. 0 . & س & $\%\urcorner . \wedge V$ & 09.10 & 00.91 & قوة عضلات الظهر \\
\hline$\% \vee .+1$ & Tr. & $0 \wedge .0$. & $\%$ \%.r. & 77.4. & $09 .$. & التوازن الديناميكى \\
\hline$\% 11.1$ & rT.r. & $r \cdot .9$. & \% \% & rı... & rI. r. & المرونة الديناميكية \\
\hline
\end{tabular}

يتضح من جذول (r ا () تفوق أفر اد المجموعة التجريبية على أفر اد المجموعة الضابطة فى نسب تحسن القياس البعدى عن القبلى في القدرات البدنية الخاصة قند جيد البحث.

جدول (r) (1)

دلالة الفروق بين القياسين القبلى والبعدى للمجموعة التجريبية في المستوى الرقمى فى قنف القرص

\begin{tabular}{|c|c|c|c|c|c|c|}
\hline \multirow{2}{*}{ قيمة "ت" } & \multicolumn{2}{|c|}{ القياس البعدى } & \multicolumn{2}{|c|}{ القياس القبلى } & \multirow{2}{*}{ وحدة } & \multirow{2}{*}{ المتغير } \\
\hline & $\varepsilon$ & س س & $\varepsilon$ & س & & \\
\hline$* \varepsilon .09$ & $\because v 7$ & .... &.$\wedge T$ & סע. ו" & منر & فى قذف القرص \\
\hline
\end{tabular}

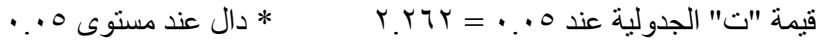

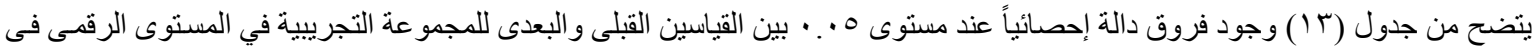
قذف القرص لصالح القياس البعدى.

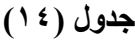

دلالة الفروق بين القياسين القبلى والبعدى للمجموعة الضابطة في المستوى الرقمى فى قذف القرص

\begin{tabular}{|c|c|c|c|c|c|c|}
\hline \multirow{2}{*}{ قيمة "ت" } & \multicolumn{2}{|c|}{ القياس البعدى } & \multicolumn{2}{|c|}{ القياس القبلى } & \multirow{2}{*}{ وحدة القياس } & \multirow{2}{*}{ المتغير } \\
\hline & $\varepsilon$ & س س & $\varepsilon$ & 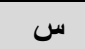 & & \\
\hline$* r . \leqslant 1$ & $\because \wedge \varepsilon$ & T.90 & .91 & (.... & 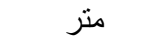 & المسنوى الرقمى فى قذف القرص \\
\hline
\end{tabular}

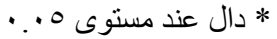

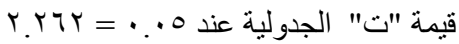

يتضح من جدول (ع ( ) وجود فروق دالة إحصائياً عند مستوى 0. . • بين القياسين القبلى و البعدى للمجموعة الضابطة في المستوى الرقمى فى قذف القرص لصالح القياس البعدى.

جدول (10)

دلالة الفروق بين القياسين البعديين للمجموعتين التجريبية والضابطة في المستوى الرقمى فى قذف القرص

\begin{tabular}{|c|c|c|c|c|c|c|}
\hline \multirow[t]{2}{*}{ قيمة "ت" } & \multicolumn{2}{|c|}{ المجموعة الضابطة ن= } & \multicolumn{2}{|c|}{ المجموعة التجريبية } & \multirow{2}{*}{ والقياسة } & \multirow[t]{2}{*}{ المتغير } \\
\hline & $\varepsilon$ & 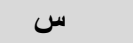 & $\varepsilon$ & س س & & \\
\hline$* Y . \vee \wedge$ & $\because \wedge \varepsilon$ & 11.90 & $\because \vee 7$ & (r... & 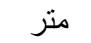 & المستوى الرقمى فى قذف القرص \\
\hline
\end{tabular}

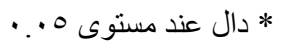

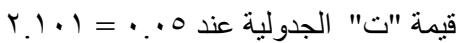

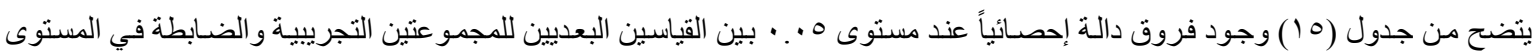
الرقمى فى قذف القرص لصالح المجمو عة التجريبية.

جدول (18)

نسب تحسن القياس البعدى عن القبلى للمجموعتين التجريبية والضابطة في المستوى الرقىى فى قذف القرص

\begin{tabular}{|c|c|c|c|c|c|c|}
\hline \multicolumn{3}{|c|}{ المجموعة الضابطة } & \multicolumn{3}{|c|}{ المجموعة التجريبية ن = } & \multirow{2}{*}{ المتغير } \\
\hline نسب التحسن & بعدى & قبلى & نسب التحسن & بعدى & قبلى & \\
\hline$\% r .7$ & 4.90 & r... & $\% 0 . Y 7$ & Tr... & r. & فى قذف القرص \\
\hline
\end{tabular}


يتضح من جدول (7 1 ) تفوف أفر اد المجموعة التجريبية على أفر اد المجموعة الضابطة فى نسب تحسن القياس البعدى عن القبلى في المستوى الرقمى فى قذف القرص.

ثنانياً: مناقشة النتائج : أن أ ـ مناقثة نتائج الفرض الأول للبحث:

بملاحظة نتائج جدول (9) يتضح وجود فروق دالة إحصائياً عند مستوى ه •. • بين القياسين القبلى والبعدى للمجمو عـة التجرييية في القدرات البدنية الخاصة (القدرة العضلية للذر اعين ـ القدرة العضلية للرجلين - قوة عضلات الظهر - التوازن الديناميكى ـ المرونة الديناميكية) لصالح القياس البعدى.

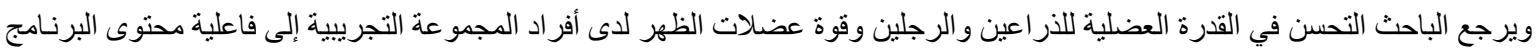

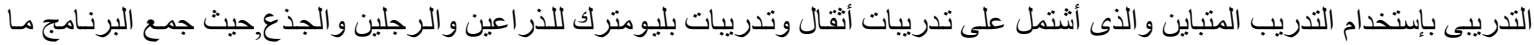

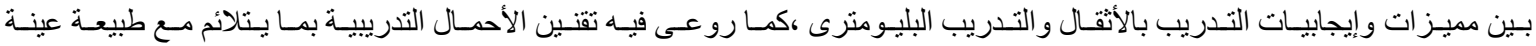

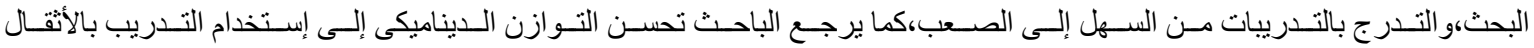

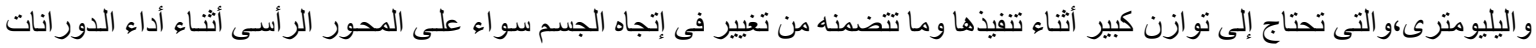

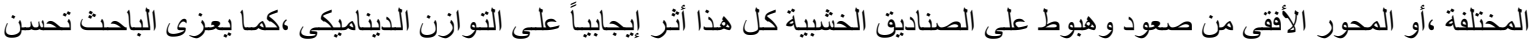

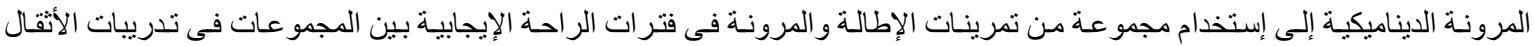

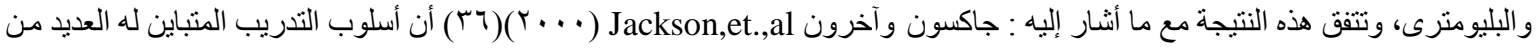

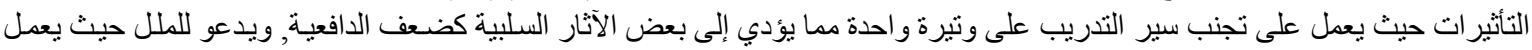

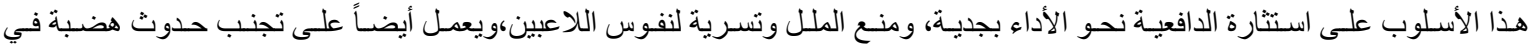

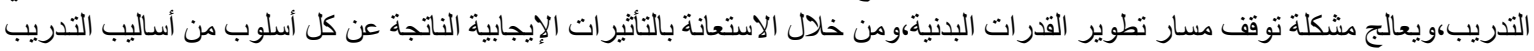

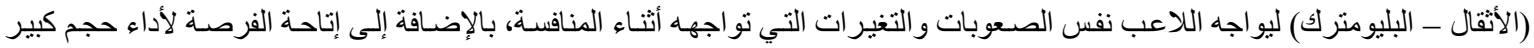

داخل الوحدة التدريبية.

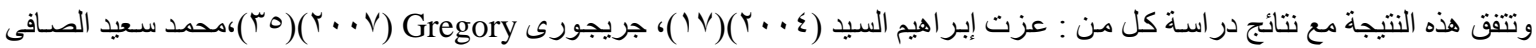

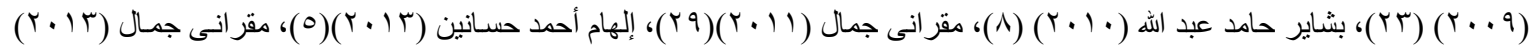

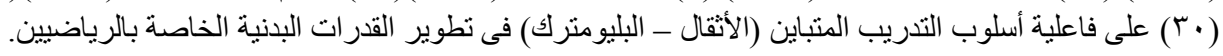

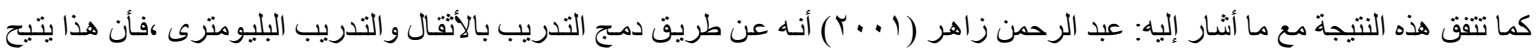

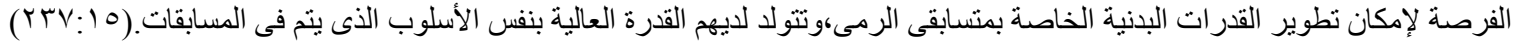
كما أسفرت نتائج جدول (• (1) عن وجود فروق دالة إحصائباً عند مستوى ه . . • بين القياسين القبلى و البعدى للمجموعة الضـابطة في القدرات

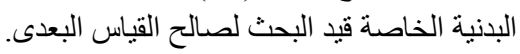

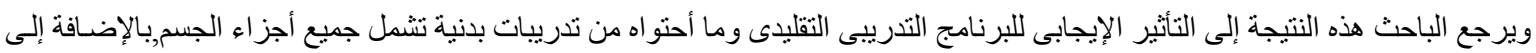

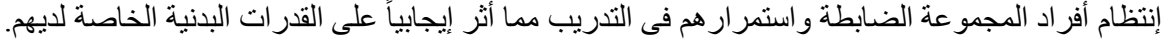

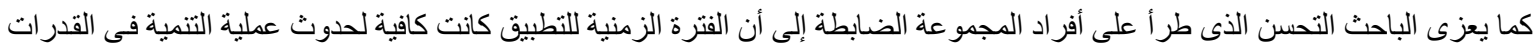

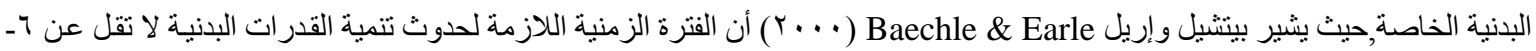

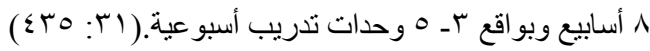

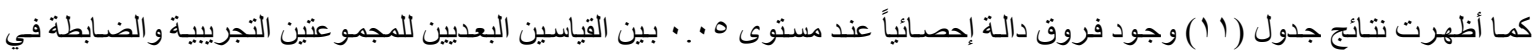

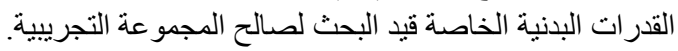

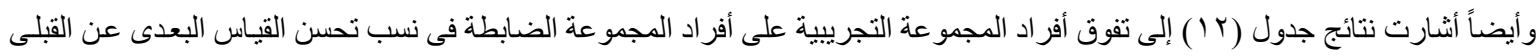
في القدر ات البدنية الخاصة قبد البحت (1)

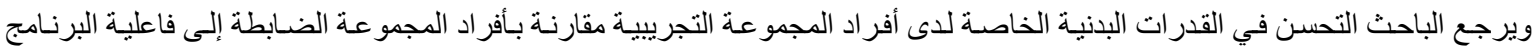

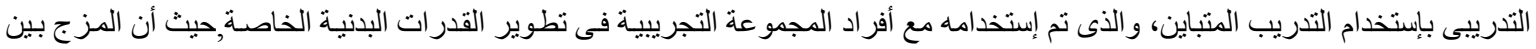

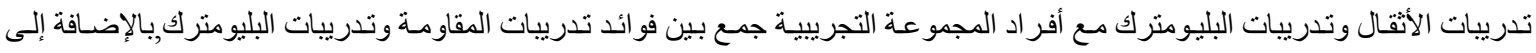

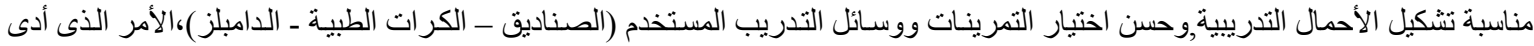

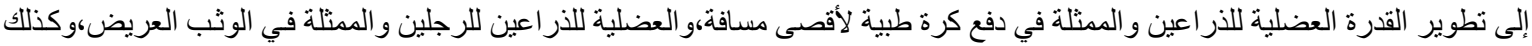

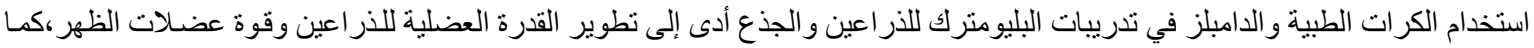




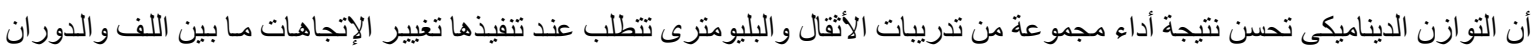

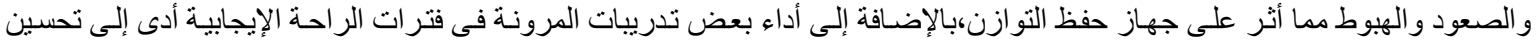

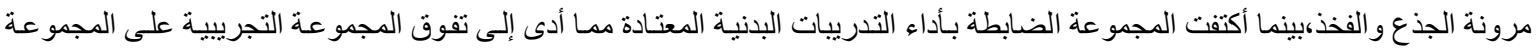
الضابطة فى القياسات البعدية ونسب التحسن.

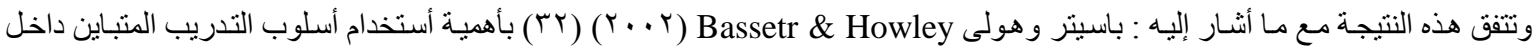

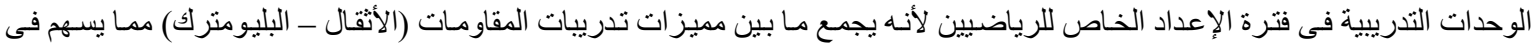

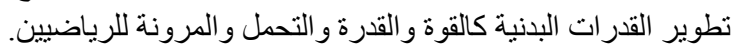

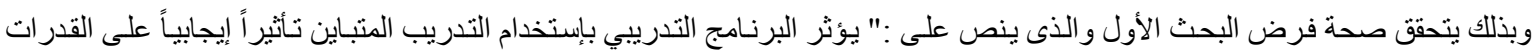

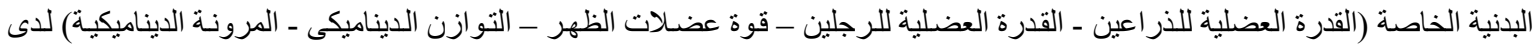

تلاميذ المدرسة الثانوية الرياضية".

ب - مناقشة نتائج الفرض الثانى للبحث:

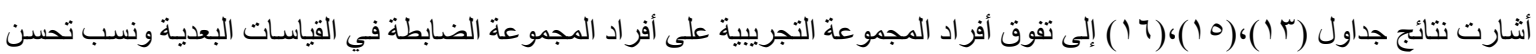

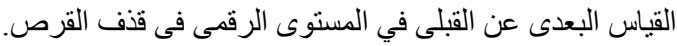

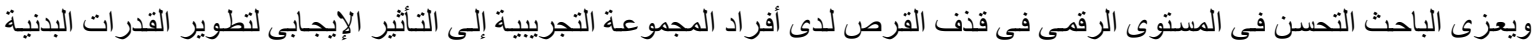

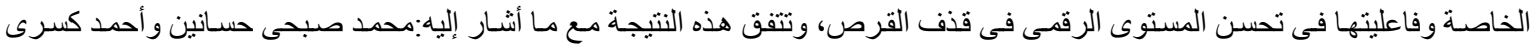

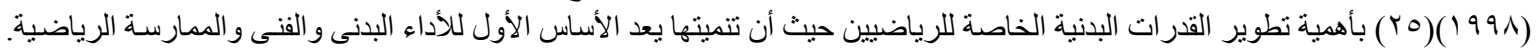

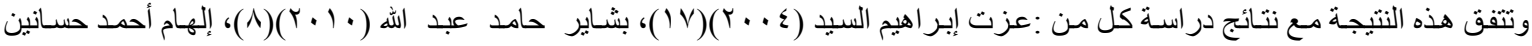

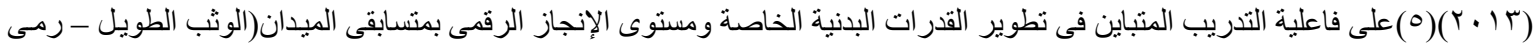

الرمح).

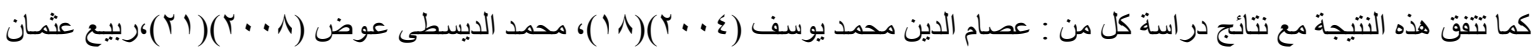

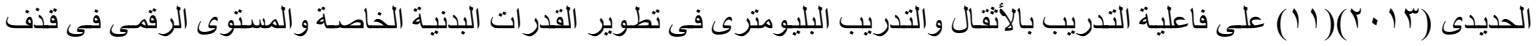

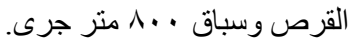

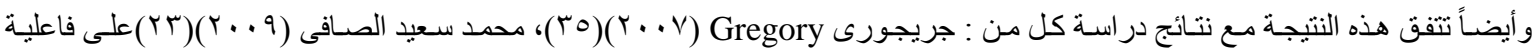

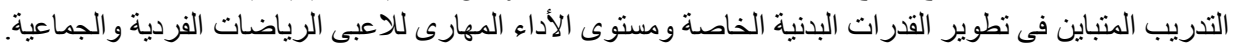

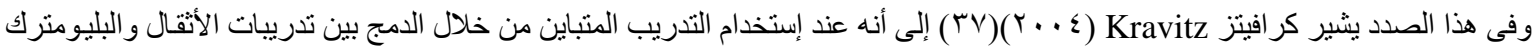

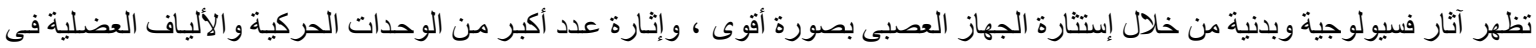

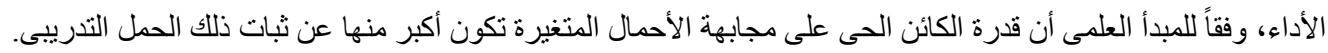

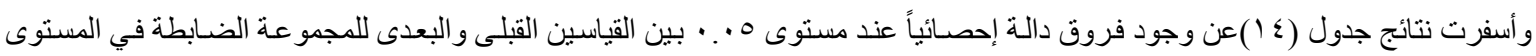
الرقمى فى قنف القرص لصالح القياس البعدى.

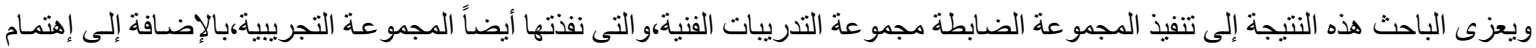

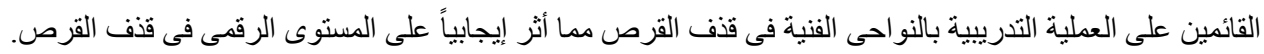

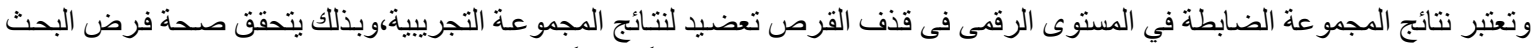

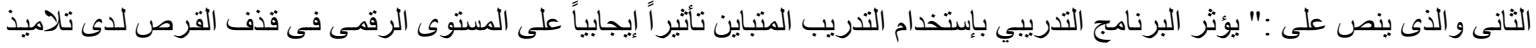
المدرسة الثانوية الرياضية".

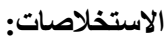

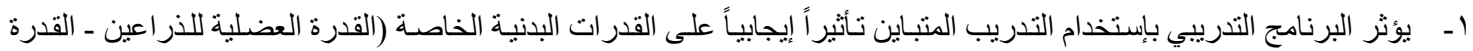
العضلية للرجلين - قوة عضلات الظهر ـ التو ازن الديناميكى ـ المرونة الديناميكية) لدى تلاميذ المدرسة الثانوية الرياضية.

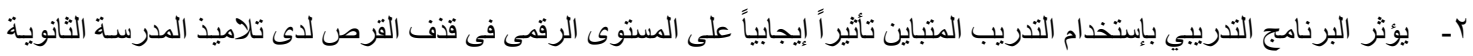
الرياضية.

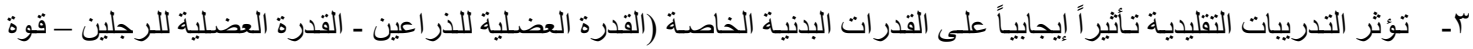

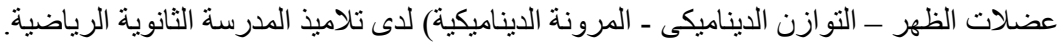


ع - تؤُثر التدريبات التقليدية نأثير أيجابياً على المستوى الرقمى فى قذف القرص لدى تلاميذ المدرسة الثانوية الرياضية.

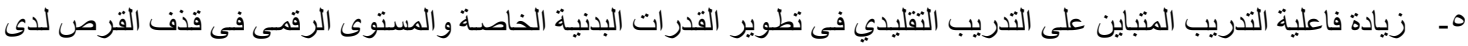
تلاميذ المدرسة الثانوية الرياضية.

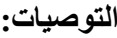

فى حدود عينة البحث ، وفى ضوء نتائجه يوصى الباحث بما يلى: ا - إستخدام التدريب المنباين (التدريب بالأثقال + التدريب البليومترى) لتطوير القدرات البدنية الخاصة لما لـه من أثر فعال فى تحسين المستوى الرقمى فى قذف القرص لإى تلاميذ المدرسة الثانوية الرياضية.

r- ـ الإهتمام بتمرينات الإطالة و المرونة عند تطبيق التدريب المتباين لتلافى التأثير ات المتبادلة العكسية لتنمية القوة على المرونة. r- يجب ألا تقل فترة تطبيق البرنامج التدريبى باستخدام التدريب المتباين عن (^) أسابيع حتى يحقق نتائج جيدة. ــ - إجر اء المزيد من الدراسات العلمبة التي تتناول تأثير أسلوب التدريب المتباين بأثنكال تدرييية أخرى في مسابقات الميدان وسباقات المضمار المختلفة.

هـ إجراء در اسات أخرى عن هذا الأسلوب التدريبى تأخذ الإتجاه الفسيولوجى و النفسى للتعرف على فاعلية هذا الأسلوب بشكلاً كامل.

المراجع:

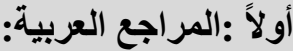

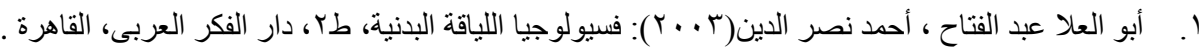

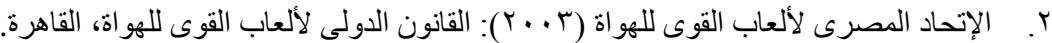

r. . السيد عبد المقصود ( (99 (1)): نظريات التدريب الرياضي تدريب وفسيولوجيا التحمل ، مطبعة الثباب الحر ، القاهرة.

؛. السيد عبد المقصود (999 (1): نظريات التدريب الرياضي - تدريب وفسيولوجيا القوة، مركز الكتاب للنشر ، القاهرة.

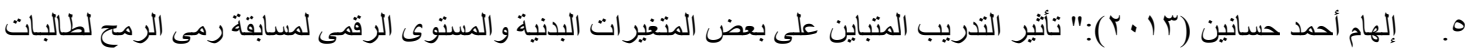
كلية التربية الرياضية بالمنيا"،رسالة ماجستير، كلية التربية الرياضية ، جامعة المنيا.

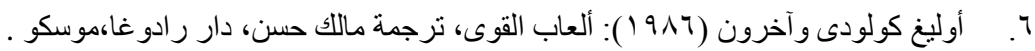
V. بسطويسى أحمد بسطويسى (Y99 ( )): سباقات المضمار ومسابقات الميدان - تعليم ـ تكنيك - تدريب، دار الفكر العربى، القاهرة .

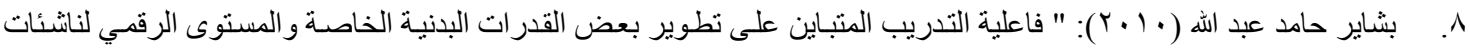

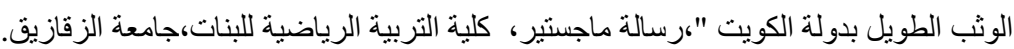

9. خيرية إبر اهيم السكرى ، سليمان على حسن (1997): دليل التعليم و التدريب فى مسابقات الرمى، منشأة المعارف، الإسكندرية.

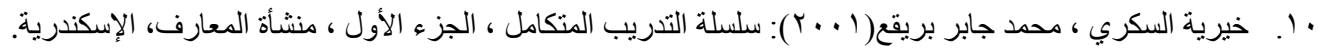

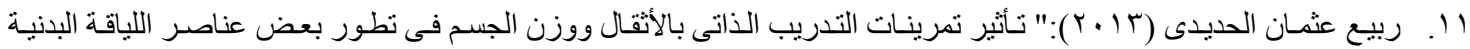

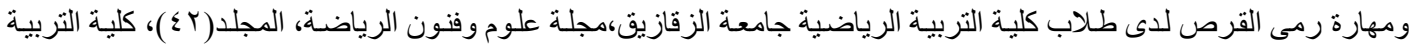
الرياضية بنات، جامعة حلو ان.

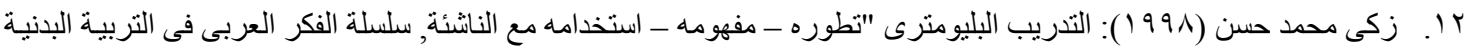
والرياضة، دار الفكر العربي, القاهرة. با. . سليمان على حسن ، أحمد الخادم ، ذكى درويش (r/911): التحليل العاملى لمسابقات الميدان والمضمار، دار المعارف، القاهرة .

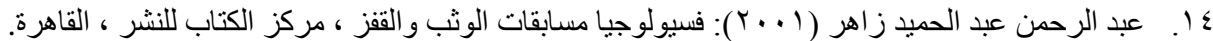




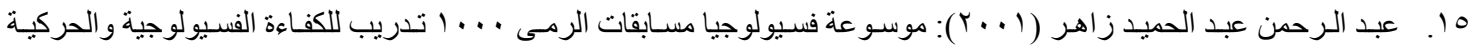
و المهارية، مركز الكتاب للنشر، القاهرة . 7 1. عبد العزيز النمر ، ناريمان الخطيب (9971)): تدريب الأثقال وتصميم برامج القوة وتخطيط الموسم التدريبي،مركز الكتاب للنشر، القاهرة.

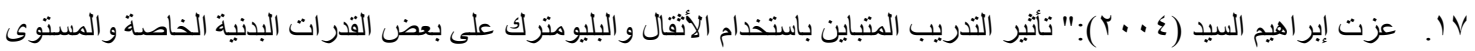

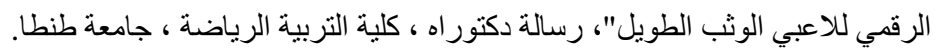

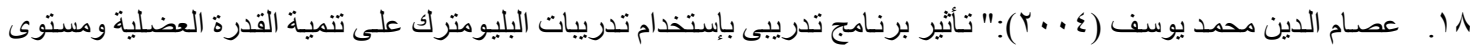
الإنجاز الرقمى لمتسابقى الرمى (الجلة ،القرص،الرمح)،رسالة دكتور اه، كلية التربية الرياضية ، جامعة أسيوط.

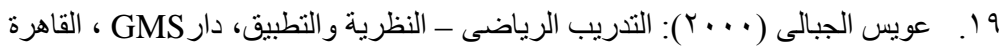
• r. . . محمد إبر اهيم شحاته (997 (1)): التدريب بالأثقال ، منشأة المعارف ، الإسكندرية.

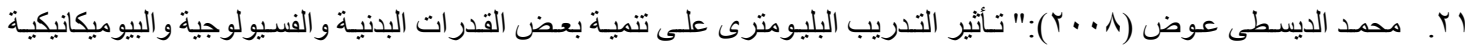

و علاقتها بالمستوى الرقمى لمتسابقى . . 1 متر جرى "، رسالة دكتور اه ،كليـة التربيـة الرياضيـة ، جامعة المنصورة.

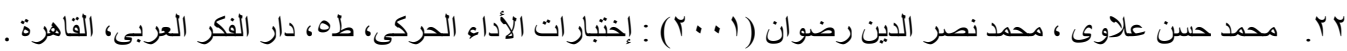

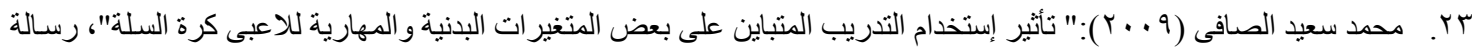
ماجستير، كلية التربية الرياضية ، جامعة المنيا.

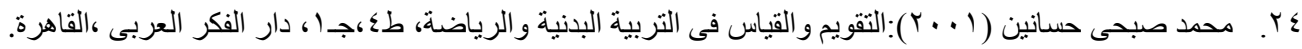
Or. محمد صبحى حسانين ، أحمد كسرى (1991) ): موسوعة التدريب الرياضى التطبيقى ، مركز الكتاب للنشر، القاهرة.

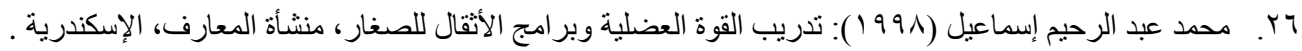

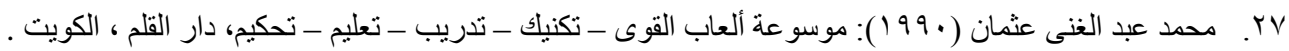
אץ. محمد محمود عبد الدايم ،مدحت صسالح ،طارق قطان (ب99 (19): بر امج تدريب الإعداد البدنى وتدريبات الأثقال، مطابع الأهرام، القاهرة .

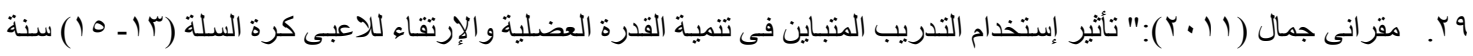

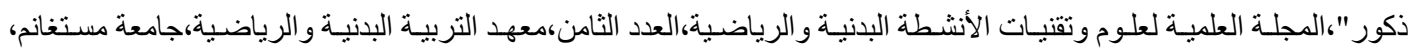
الجزائر.

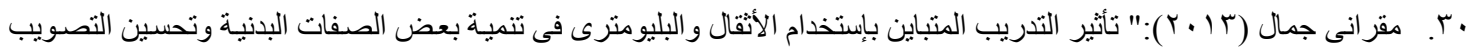

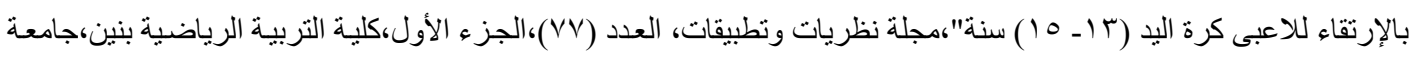
الإسكندرية.

\section{ثانياً :المراجع الأجنبية:}

31. Baechle,T., \& Earle,R.,(2000): Essentials of strength training and conditioning 2nd ed, Human kinetics.

32. Bassetr, D., \& Howley, E.,(2002): Maximal oxygen uptake: "classical" versus "contemporary" viewpoints", Medicine and science in sports and exercise, vol. 29, no. 5, pp. 591-603. 
33. Bastiaans, J., et.,al (2000):The effects ofreplacing a portion of endurance training byexplosive strength training on performance in trained cyclists. EurJ Appl Physiol 2001: 86: 79-84.

34. Donald, A .,chu (1998) : Jumping in to plyometric, ed, Human kinetics, California.

35. Gregory, T., (2007): The Effect of Concurrent Resistance and Endurance Training on Physiological and Performance Parameters of Well Trained Endurance Cyclists, Master's Thesis, School of Exercise, Biomedical, and Health Sciences, Edith Cowan University.

36. Jackson, R., et.,al (2000): Potential for strength and endurance training to amplify endurance performance. J Appl Physiol 65:2285-2290.

37. Kravitz, L., (2004). The effect of concurrent training. IDEA Personal Trainer, 15(3), 34-37. 


\section{الملخص باللغة العربيـة}

تأثير إستخدام التدريب المتباين لتنمية بعض القدر ات البدنية الخاصة على المسنوى الرقمى فى قذف القرص. حسام كمال الدين محمود أبو المعاطى قسم نظريات وتطبيقات مسابقات الميدان والمضمار ـ كلية التربية الرياضية بنين - جامعة الزقازيق - جمهورية مصر العربية.

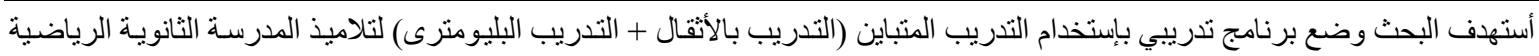
ومعرفة تأثيره على: التئ ا ــ القدر ات البدنية الخاصة (القدرة العضلية للذر اعين ـ القدرة العضلية للرجلين ـ قوة عضلات الظهر ـ التوازن الديناميكى ـ المرونـة الديناميكية) لاى تلاميذ الدرسة الثانوية الرياضية.

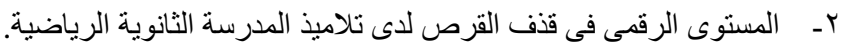

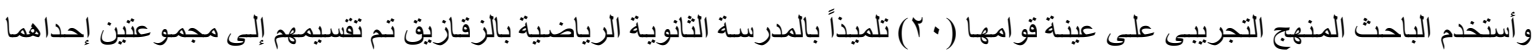

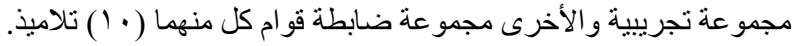

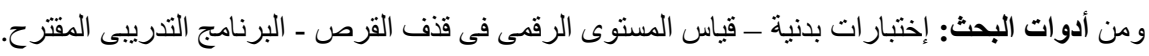

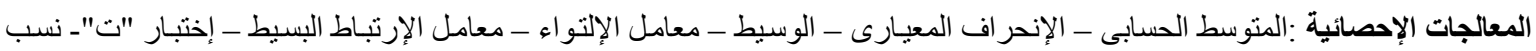

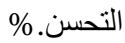
ومن أهم النتائج:

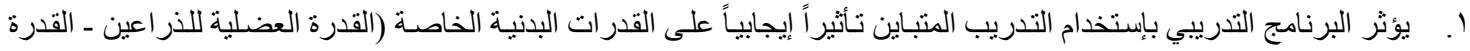

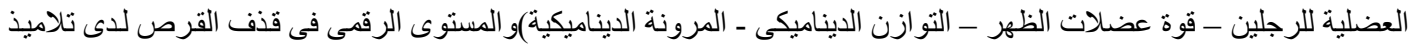

المدرسة الثانوية الرياضية. ومن أهم التوصيات:

ا - إستخدام التدريب المتباين (التدريب بالأتقال + التدريب البليومترى) لتطوير القدرات البدنية الخاصة لما لـه من أثر فعال فى تحسين المستوى الرقمى فى قذف القرص لدى تلاميذ المدرسة الثانوية الرياضية. ז- الإهتمام بتمرينات الإطالة والمرونة عند تطبيق التدريب المتباين لتلافى التأثير ات المتبادلة العكسية لتنمية القوة على المرونة. 
The Effeetiveness of Core Stability Exercises on the Level of Production Power the Sports Team Players.

\section{Hossam Kamal al-Din Mahmoud}

The research was developing a training program using differential training (training with weights + training Albleomtry) for pupils of secondary school sports and see its impact on:

1- physical capabilities (the ability of the arms muscle - the muscle power of the two men - the power of the back muscles - dynamic equilibrium - dynamic flexibility) to the students of secondary school sports.

2- digit level throwing disk with pupils of secondary school sports

And research tools: physical tests - to measure the digital level throwing disk - the proposed training program.

\section{Among the most important results:}

1. Upon the pupils of secondary school sports training program using differential training has a positive effect on your physical abilities (ability of the arms muscle - the muscle power of the two men - the power of the back muscles - Dynamic - Dynamic flexibility) and digital equilibrium level in the extrusion disk.

\section{One of the main recommendations}

1. The use of the Variant training (training with weights + training Albleomtry) to develop physical capabilities because of its significant impact in improving the digital level in the extrusion disk with pupils of secondary school sports.

2. interest prolongation exercises and flexibility training when the differential application to prevent the adverse effects of the mutual development of the power of flexibility. 
